\title{
A REVIEW OF BUILDING INFORMATION MODELING RESEARCH FOR GREEN BUILDING DESIGN THROUGH BUILDING PERFORMANCE ANALYSIS
}

\author{
SUBMITTED: April 2018 \\ REVISED: August 2019 \\ PUBLISHED: January 2020 at https://www.itcon.org/2020/1 \\ EDITOR: Kumar B. \\ DOI: $10.36680 /$ j.itcon.2020.001 \\ Yun-Tsui Chang \\ Department of Civil Engineering, National Taiwan University; \\ ytchang1988@gmail.com
}

\author{
Shang-Hsien Hsieh \\ Department of Civil Engineering, National Taiwan University; \\ shhsieh@ntu.edu.tw
}

\begin{abstract}
SUMMARY: The strength of Building Information Modeling (BIM) in achieving sustainable buildings is well recognized by the global construction industry. However, current understanding of the state-of-the-art green BIM research is still limited. In particular, a focus study on how BIM contribute to green building design through building performance analysis (BPA) is not available. This paper aims to provide systematic and comprehensive insights on current trends and future potentials of green BIM research by analyzing the existing literature with their research features (i.e. research backgrounds, goals, methods and outputs). In total, 80 publications have been collected, analyzed and discussed. The results show that among ten main BPA types, energy \& thermal analysis, green building rating analysis, and cost and benefit analysis are the most studied. However, wind \& ventilation analysis, acoustic analysis, and water efficiency analysis receive little attention. Moreover, more research focusing on integrated design analysis should be carried out for optimal design outcome. In addition, most of the collected literature research on the capability of data integration and analysis of green BIM tools, while their capability of visualization and documentation has limited examination. Furthermore, most researchers utilized one main software package while utilization of information exchange formats (IEF) is limited. To increase interoperability of green BIM tools, how different BIM authoring tools and IEFs can be utilized for BPA requires further investigation.
\end{abstract}

KEYWORDS: Green Building Information Modeling (BIM), Building Performance Analysis (BPA)

REFERENCE: Yun-Tsui Chang, Shang-Hsien Hsieh (2020). A review of Building Information Modeling research for green building design through building performance analysis. Journal of Information Technology in Construction (ITcon), Vol. 25, pg. 1-40, DOI: 10.36680/j.itcon.2020.001

COPYRIGHT: (C) 2020 The author(s). This is an open access article distributed under the terms of the Creative Commons Attribution 4.0 International (https://creativecommons.org/licenses/by/4.0/), which permits unrestricted use, distribution, and reproduction in any medium, provided the original work is properly cited. 


\section{INTRODUCTION}

The concept of "green building" arose in the 1990s in response to the considerable environmental problems that the building sector has caused worldwide (Zuo \& Zhao 2014). However, the development of green building today is still hindered by many obstacles (Hwang \& Tan 2012). One of the main barriers is the lack of integrated tools to consider multiple green building aspects from early project stages for optimal decision making (Häkkinen \& Belloni 2011). As an emerging technology, building information modeling (BIM) seems to be one of the key approaches to address this problem. For example, integrated project delivery (IPD) and design optimization can be achieved for the production of green building design with the utilization of BIM (Wong \& Fan 2013).

Despite "green BIM" having become a popular concept in the building sector over the last few years (McGrawHill 2010), there are limited systematic reviews on current research efforts concerning how green BIM aids in green building design. For example, Wong and Zhou (2015) conducted a comprehensive review of green BIMrelated journal papers by four key project stages. Nevertheless, it lacks a systematic review on green BIM literature based on green building aspects nor building performance analysis (BPA) types, which leads to a lack of knowledge of how green BIM can currently serve as an integrated green building design tool. Later on, Chong et al. (2017) also tempted to examine the adoption of BIM for sustainability. This time, they collected different types of literature (including standards, guidelines, journal and conference papers) and analyzed them by five key project stages and two key green building aspects. However, their work does not focus on green BIM research for design stage and their discussion on green building aspects are minimal, thus hindering them to examine green BIM research comprehensively. In addition, Lu et al. (2017) also collected green BIM related journal papers in order to provide more insights on green BIM research. They proposed a "green BIM triangle" taxonomy, and examined the collected literature by four project phases, six green attributes and four BIM attributes. Nonetheless, conference literature is neglected and several important BPA types are also overlooked in their work.

In order to fill the research gaps mentioned above, this paper aims to provide systematic and comprehensive insights on current trends and future potentials of BIM research for green building design through BPA. The existing literature is analyzed by their research features (i.e. research backgrounds, goals, methods and outputs). Both journal and conference papers are included in the collected literature in order to trace emerging research trends. And they are tagged by ten key BPA types for in depth analysis. Furthermore, BIM authoring, programming, simulation tools used in the collected papers are also highlighted for further discussion.

\section{GREEN BUILDING INFORMATION MODELING AND BUILDING PERFORMANCE ANALYSIS}

\subsection{BIM for building performance analysis (BPA)}

The term "green building" has been used interchangeably with "high-performance building" (Zuo \& Zhao 2014). A high-performance building, according to the Energy Independence and Security Act (NIBS 2011), involves the optimization and integration of all major performance attributes of a building on a life cycle basis. These include not only environmental sustainability (e.g., energy conservation), but also other aspects such as cost-benefit, occupant productivity, and operational considerations. Hence, the key to a high-performance building is the optimization and integration of different building systems. To achieve a high-performance building, BIM can play an important role in generating iterations of the building model for optimal design decisions and enhancing interaction among project team members in the design process (Wong \& Zhou 2015).

To investigate the viability of BIM-based sustainability analyses, Azhar and Brown (2009) conducted a series of questionnaire survey and semi-structured interviews. First, they discussed the synergy of building information models and performance analysis software. A building information model contains basic information such as building geometry, weather conditions, building materiality, building systems etc. Based on this information and the additional information entered into the performance analysis software, the environmental performance of a building can be evaluated and optimized. Currently, performance analysis software mainly focuses on thermal, energy, solar, lighting/daylighting, acoustic, and value/cost analysis (Azhar \& Brown 2009).

Through their questionnaire survey, Azhar and Brown (2009) identified the key BPA types and BIM-based performance analysis software adopted in respondents' firms. Energy analysis, daylight/solar analysis, and LEED documentation were the most used analysis types. Meanwhile Autodesk Green Building Studio (GBS), Autodesk Ecotect, and IES Virtual Environment were the most-used analysis software packages. Furthermore, Azhar and Brown (2009) developed an evaluation matrix for the comparison of these three most used analysis software 
products. Seven key analysis types (i.e., energy, thermal, solar, lighting/ daylighting, acoustic, value/ cost analysis, LEED integration tool) and their weighting were identified. The results considered IES the best software for BIMbased sustainability analysis.

Besides Azhar and Brown (2009), Reeves et al. (2012a, 2015) also evaluated various building energy modeling (BEM) tools to provide guidelines for design and delivery of high-performance buildings. In their research, twelve BEM tools were evaluated by four criteria: interoperability, user-friendliness, available inputs, and available outputs. They have identified fifteen key outputs of these BEM tools, i.e., the BPA types, which include energy usage, thermal analysis, heating/cooling load, HVAC, carbon emissions, resource management, solar analysis, daylighting, right to light, shading, artificial light, natural ventilation, lifecycle analysis, lifecycle cost, and water usage. In their initial evaluation of the BEM software tools, IES Virtual Environment, Autodesk Ecotect, and Autodesk Green Building Studio were identified as the top three BEM tools. In their re-evaluation of the top three BEM tools via case study, IES Virtual Environment was identified as the best BEM tool among the three.

These two series of research (Azhar \& Brown 2009, Reeves et al. 2012a, 2015) have provided insights on the viability of BIM-based sustainability analysis. The BIM-based sustainability analysis types and tools identified and evaluated in their research are referenced in our study for the categorization and comparison of the research outcomes in existing green BIM literature.

\subsection{Green BIM issues}

Although the benefits of "green BIM" have been recognized by the construction industry, there are various issues hindering the utilization of green BIM (McGraw-Hill 2010, Bynum et al. 2012). According to McGraw-Hill's 2010 report, the main obstacles to green BIM adoption are the blunt nature of current tools and the perception that existing tools are easier to use than green BIM. According to the survey conducted by Bynum et al. (2012), although BIM is perceived as a multidisciplinary tool, problems with interoperability continue to hold up various BIM applications in the industry. Solving the interoperability problems of various green BIM tools can be regarded as one of the most urgent tasks for green BIM researchers and developers.

To solve the problems with interoperability, BIM organizations and developers have created various data model exchange formats. Among these formats, Industry Foundation Classes (IFC) is the only public, non-proprietary data model, which is adopted worldwide by different governments and agencies. IFC has laid the foundation of standardized data exchange. IFC stores a complete building model and contains a class hierarchy, representing the geometry of a building in a coordinate system and building element attributes. Therefore, it is possible for IFC to model various kinds of building elements and shapes.

Another important data exchange format is Green Building XML schema (known as gbXML). This schema is particularly for data exchange between CAD and energy analysis software (Dong et al. 2007). Because of its scope, gbXML contains a great amount of values enabling simulation and calculation of thermal loads and processes (Kofler \& Kastner 2010). Moreover, it can be linked with BIM software and implemented in a fast and simple manner because of its XML structure.

Besides utilizing these popular data exchange formats to solve the interoperability problems for BIM process, green BIM researchers and developers have also utilized Application Programing Interface (API) for customized information exchange and expansion of BIM capacity (Ding et al. 2014). BIM API enables the extension of BIM packages via several programing languages such as C\# and Visual Basic (Marzouk et al. 2013).

Research efforts made in solving interoperability problems and expanding green BIM capacity for design and delivery of high-performance buildings are also noted and highlighted in our review and analysis work of the existing green BIM literature.

\section{METHODOLOGY}

The methodological model proposed by Vom Brocke et al. (2009) is used in our study. This model is based on a five-phase framework, highlighting the importance of documenting the literature search and analysis process.

Review scope

To clearly define the scope of this literature review, the taxonomy presented by Cooper (1988) is utilized in this study, which includes six characteristics for literature review: 
(1) Goal: The aim of this study is to provide insights on the current progress and future potential of BIM research for green building design via BPA.

(2) Focus: This review concerns research features (i.e. goals, methods, outputs) of green BIM research.

(3) Perspective: This research holds a neutral position on review.

(4) Organization: This review is sorted by conceptual order first, then chronological.

(5) Coverage: The coverage of literature is comprehensive.

(6) Audience: The targeted audience is specialized scholars and practitioners of green BIM research.

\section{Literature search}

The process of our literature search is recorded below:

(1) Database source: Both search engines, Scopus and Google Scholar, are used in this study in order to cover a wider range of journals and conference proceedings (Falagas et al. 2008).

(2) Keywords and search criteria: In order to gather a wider range of green BIM research with different BPA types, the following keywords are used as shown as Table 1. When using Scopus, more detailed search setting can be made in order to gain target result. In this study, 4 groups of keywords are used together in Scopus and 16 times of literature search were conducted as keywords of Group B was changed each time as shown as Table 1. This generated a collection of about 160 pieces of literature. Meanwhile, when using Google Scholar, such detailed search setting cannot be made. Therefore, only keywords of Group A and $\mathrm{B}$ are used for search in Google Scholar in order to gain more relevant result. 16 times of literature search were also made in Google Scholar as in Scopus, and the first 50 pieces of search results were gathered each time, resulting in a total collection of 800 papers. To sum up, around 1000 papers were gathered from both search engines as our preliminary collection, which was conducted in January 2017.

(3) Evaluation and selection: Since our research focus is on BIM research for green building design through BPA, literature which is not focus on BPA, design stage and building are excluded from our collection. Moreover, some literature is also excepted as falling into the categories of editorials, theses, presentations, and research written in languages other than English. After this selection process, search results from Scopus and Google Scholar have concentrated to about 70 and 320 papers separately. Furthermore, some papers showed more than once during the 16 times search process. After eliminating the over tagged papers, search results have reduced to 38 and 65 respectively. Lastly, after eliminating the overlapped papers from both search engines, a final collection of 80 papers was concluded, including 42 journal and 38 conference papers (as shown as Table A1 in Appendix).

Table 1. Keywords used for literature search in both search engines

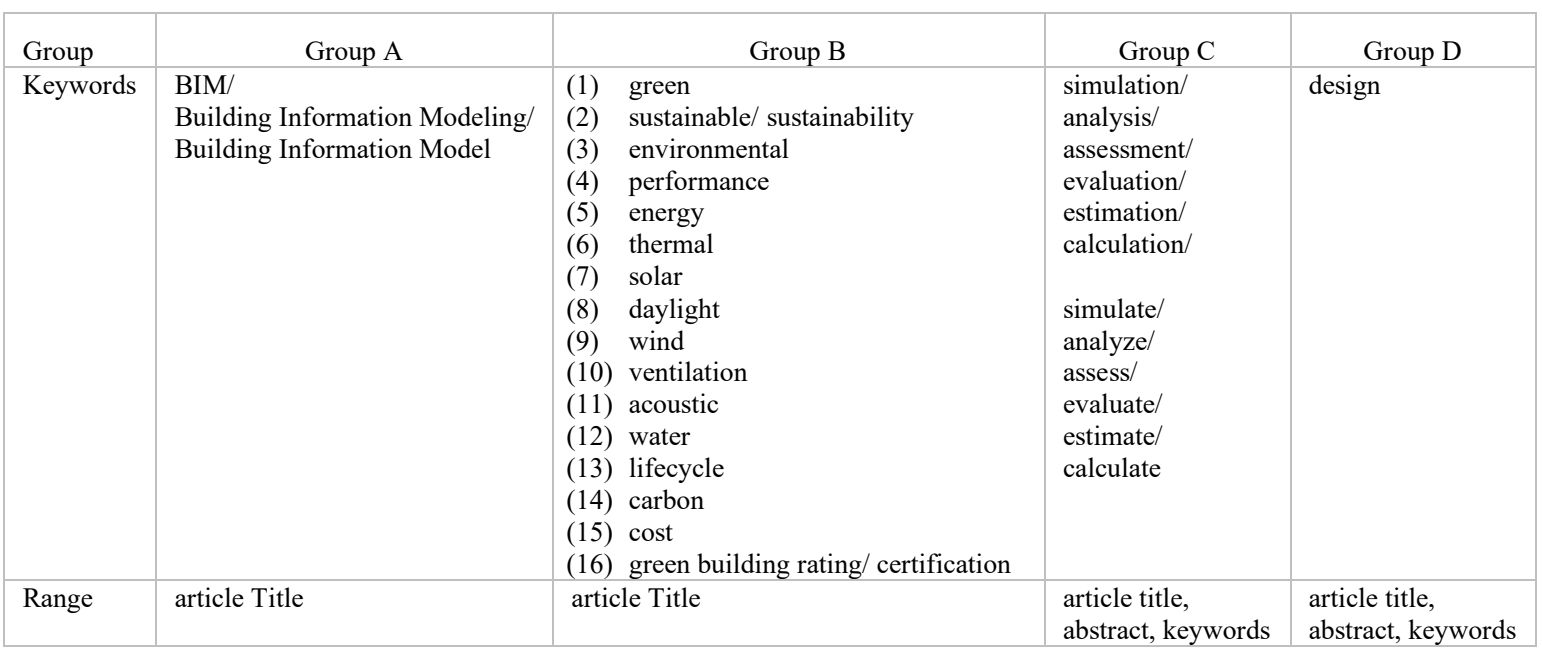

\section{Conceptualization of topic}

In order to conduct a systematic and comprehensive analysis on green BIM research, this study looks into the research features of the collected literature, which include their research backgrounds, goals, methods, and outputs. The essential information for notation are shown in Fig. 2 and explained as following:

(1) Research background: The publication years and countries of research affiliations are recorded in order to have a basic picture of green BIM research. 
(2) Research goal: What BPA types and BIM uses are studied in the collected literature are identified as their central research goals for analyses and discussions. Ten key BPA types are chosen in this study based on the frameworks developed by Azhar and Brown (2009) and Reeves et al. (2012, 2015). To be noticed, some BPA types are grouped together for they are based on the same physics principles (i.e. solar \& daylighting analysis and wind \& ventilation analysis), while others are grouped for they are closely related (i.e. thermal \& energy analysis). These groupings are for better generation of discussion. Five main BIM uses are highlighted based on frameworks developed by Lu et al. (2017). To be noticed, different from their work, design optimization is included in this study for it is an important aspect for design research. Moreover, categorization of green BIM tool application or development is also set to examine their research focus. Their difference can be understood as the former one is about application of existing green BIM tools, while the other is further development with or beyond the existing tools.

(3) Research method: General research methods (including literature review, interview, case study) are tagged in order to analyze the collected literature. Furthermore, the building types of case study and green BIM tools studied (including BIM authoring tools, formats, programming tools, languages, simulation tools and analysis modules) are also noted in order to examine their research focuses and approaches.

(4) Research output: Research outputs are also labeled in order to examine the progress of green BIM research, which can be generally categorized by essence into soft ones (e.g. guideline) and hard ones (e.g. program).
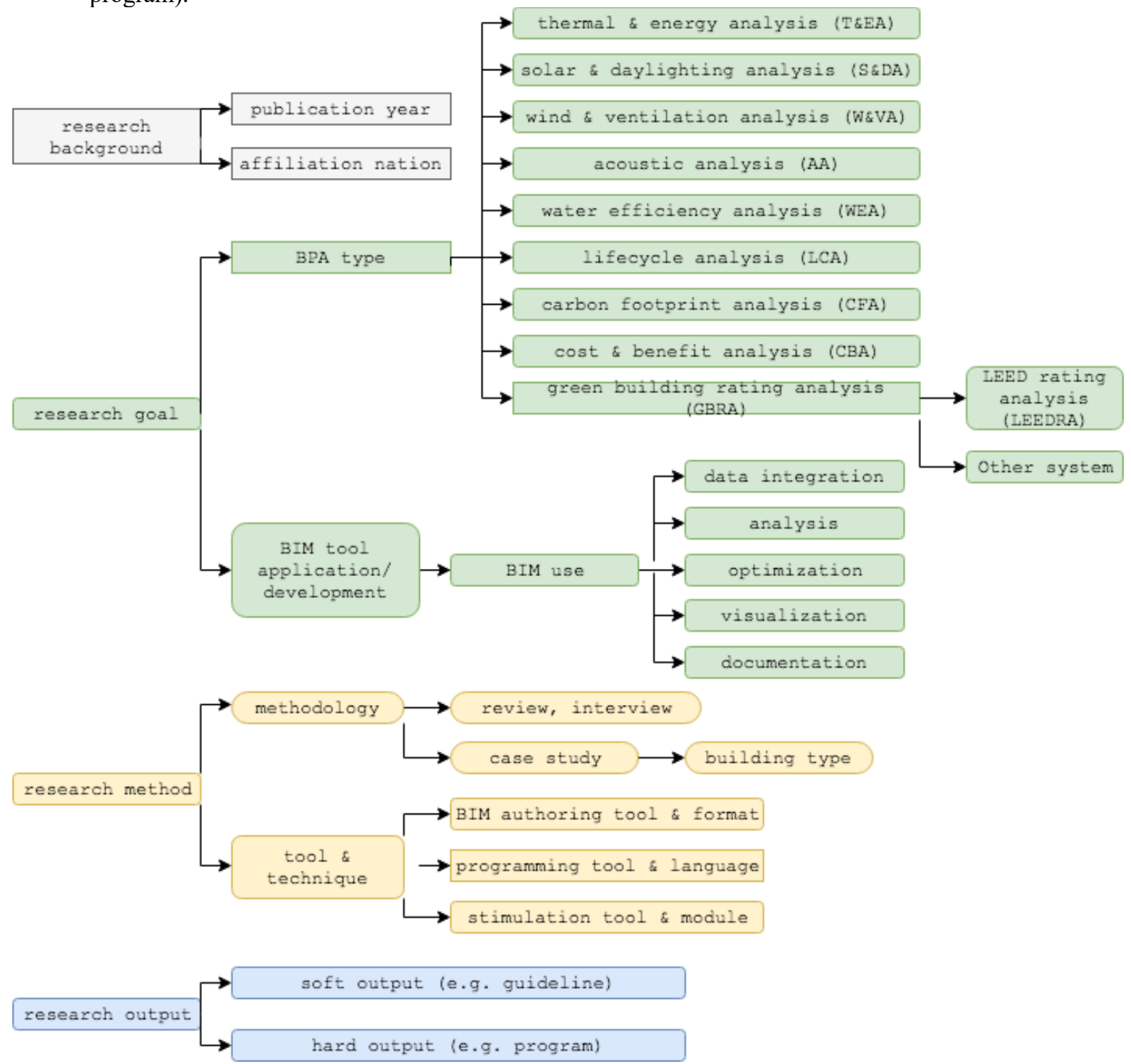

Fig 1. Research features of BIM research for green building design through BPA 


\section{Literature analysis}

The collected papers were organized to perform three types of analyses.

(1) General analysis: To draw a general trend of literature review, the collected papers are first analyzed by their research backgrounds, i.e. publication year and affiliation country.

(2) Detailed analysis: As the main focus of this study is on BIM research for BPA, the collected papers are sorted by ten key BPA types mentioned. Detailed analysis on the collected papers for each BPA type is conducted by their detailed BPA types, research goals, methods and outputs, highlighting technology used (i.e. BIM authoring tools \& formats, programing tools \& languages, simulations tools \& analysis modules)

(3) Synergy analysis: Finally, a further discussion on BIM research for integrated design via multiple BPA is carried out. Moreover, a discussion on other potential BPA types for BIM research in future is followed. Last but not the least, an overall analysis on research features of all the collected papers is presented.

\section{RESULT}

\subsection{General analysis}

On building performance analysis (BPA) types

The focus on different BPA types in the collected green BIM papers was noted, analyzed, and presented in Fig 2 and Table A2 in the Appendix. As shown in Fig 2, thermal and energy analysis (T\&EA) is the most discussed type of analysis. Green building rating analysis (GBRA) and LEED rating analysis (LEEDRA) comprise the second tier. Cost-benefit analysis (CBA) and carbon footprint analysis (CFA) are also popular research topics. Even though the importance of indoor environmental quality and water resource has been highly recognized, research on BIM for ventilation, acoustic, and water efficiency analysis is rare. These are critical topics to be researched in the future.

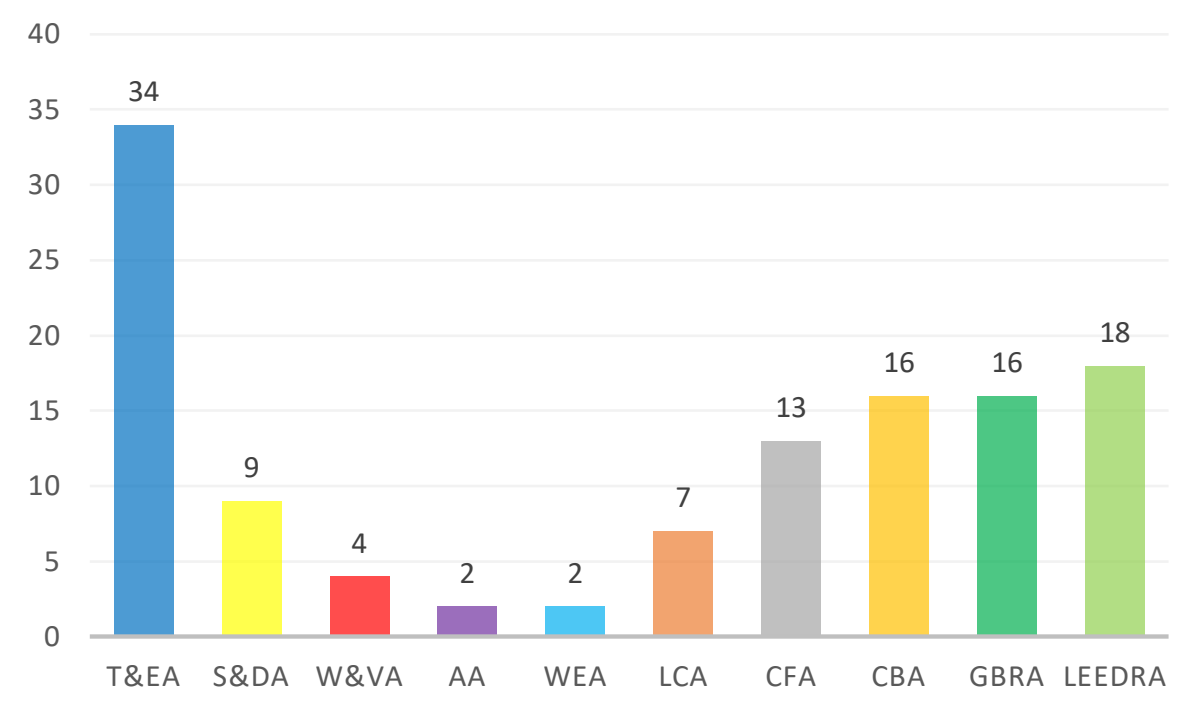

Fig 2. Green BIM research by building performance analysis (BPA) types

\section{On publication years}

As shown in Fig 3, the concept of BIM for BPA emerged around 2007. This topic started to gain more attention around 2011 and reached its peak around 2014. This shows that the importance of green BIM has been recognized by academia. However, the number of papers has dropped in recent years. Since both BIM technology and the green building industry are still under development, researchers should continue to explore the potential of BIM for BPA. 


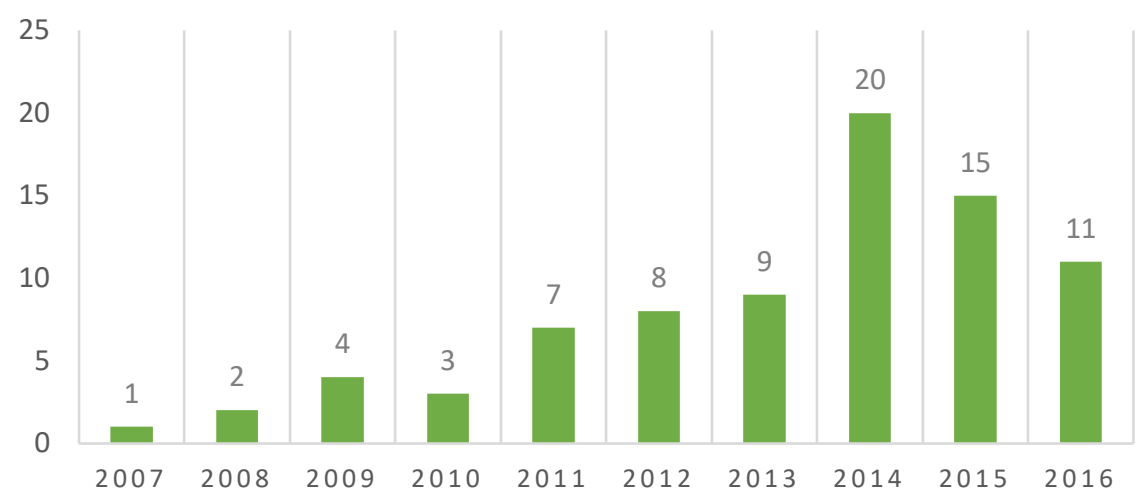

Fig 3. Green BIM research trend by publication years

Another time trend analysis is conducted with BPA types. As shown in Fig 4, study of T\&EA, GBRA, and LEEDRA has grown continually throughout the years. Since both net zero energy buildings and green building rating systems are still under development worldwide, this trend should remain. However, numbers of studies on S\&DA, W\&VA, LCA, CFA, and CBA have dropped recently. Since both climate change and economic sustainability remain as important issues, researchers should continue studying BIM for CFA and CBA.

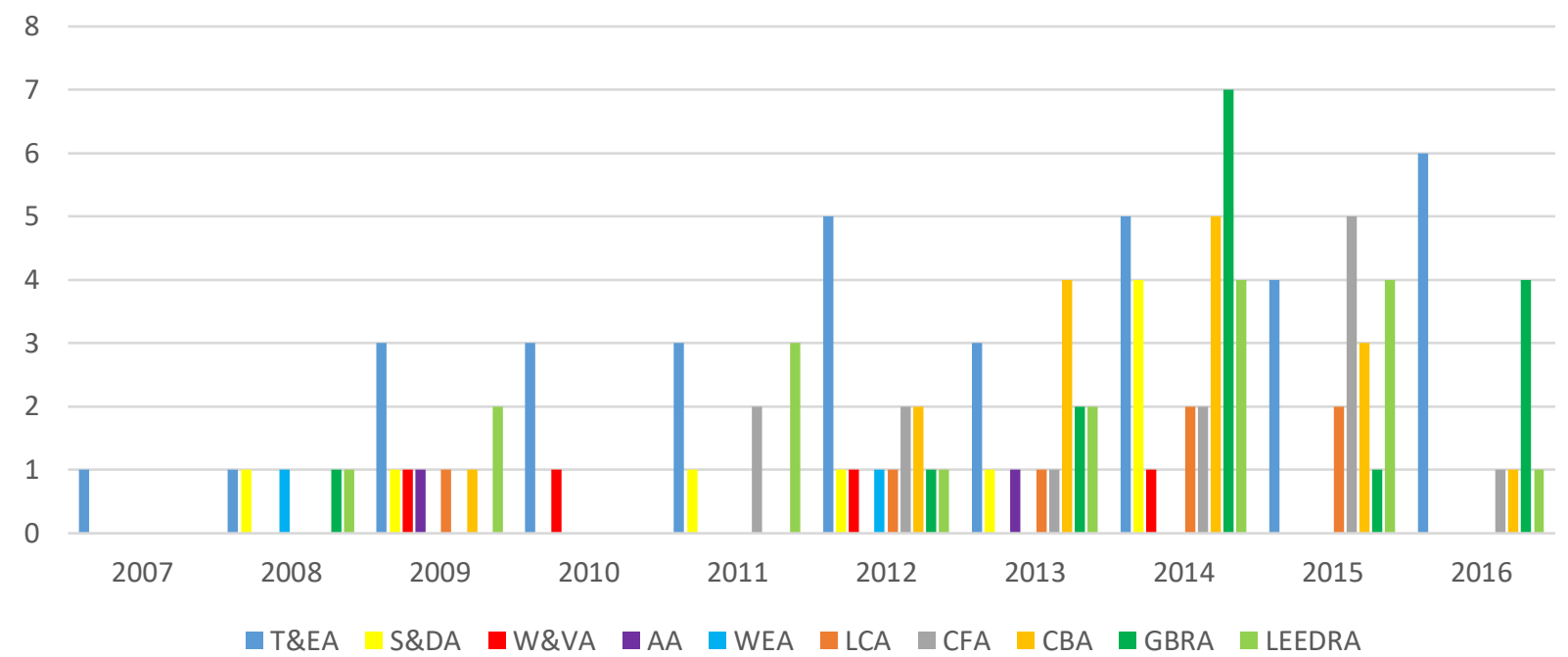

Fig 4. Green BIM research trend by publication years and BPA types

\section{On research affiliation countries}

As Fig 5 shows, the USA produced the most green BIM studies (26 papers), accounting for about 33\% in total. The UK holds second place (10), and Taiwan and South Korea tied for third (7), while Canada, Hong Kong, and China followed (6). Regionally, North American and Asian countries had almost the same amount of green BIM papers from the collected literature (32 and 31, respectively), accounting for $81 \%$ in total. Europe had only 15 $(19 \%)$. This show that green BIM has become a focal point in both North America and Asia. However, more efforts can be made and shared on this topic for European researchers.

A further analysis on the collected papers by affiliation countries and BPA types is conducted. For researchers in North America, T\&EA, S\&DA, CBA, and LEEDRA are the four most discussed BPA types. For researchers in Europe, T\&EA, LCA, and GBRA draw more of their attention. For researchers from East Asia, T\&EA, CFA, CBA, and LEEDRA are their key BPA types to focus on. For researchers from South East Asia and Oceania, GBRA is their common focus. Researchers from different places can learn lessons from one other for different BPA types. For example, researchers from North America can learn from East Asia with their research on CFA in response to their high carbon emissions by building sectors. Researchers from Asia and Oceania can learn from North America with their research on S\&DA and WEA in response to their energy and water resource shortages. 


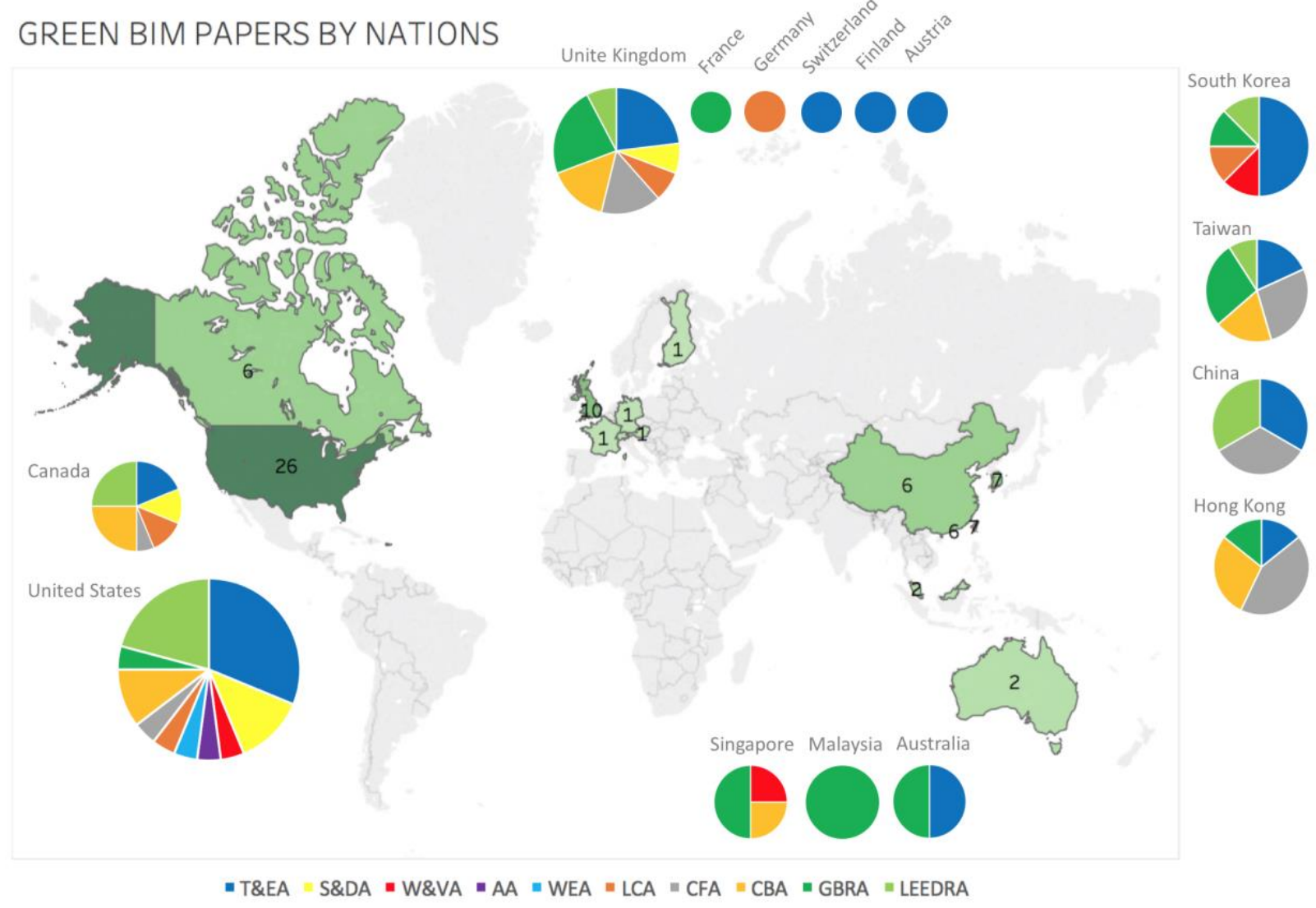

Fig 5. Green BIM literature by research affiliation countries and their BPA types

\subsection{Detailed analysis: BIM for building performance analysis (BPA)}

\subsubsection{BIM for thermal \& energy analysis (T\&EA)}

As stated in the previous section, T\&EA is the most discussed BPA type of green BIM research. This is related to the core definition and criterion of a green building: energy efficiency (Zuo \& Zhao 2014). The importance of utilizing BIM for T\&EA at early project stages is also recognized by many researchers (e.g., Schlueter \& Thesseling 2009, Stumpf et al. 2009), since it can assist designers to acquire required information for better decision making. Numerous T\&EA tools are available in the market, however their interoperability with BIM varies from tool to tool (Reeves et al. 2012a). How to improve the interoperability between T\&EA tools and BIM and increase the competency of decision makers by utilizing green BIM for early T\&EA are two important topics for researchers. Research progress of the collected literature is discussed by their research feature (i.e., research goal, research method, research output) as shown in Tables A3 and A4 in the Appendix and the following subsections.

\section{On detailed BPA types}

Most of the energy analysis discussed in these green BIM studies was limited to the energy consumption at the building operational stage. There is little research focusing on analysis of renewable energy and the embodied energy of a building. Since the importance of Net Zero Energy Buildings (NZEB) and lifecycle thinking has increased (Cho et al. 2010, Yuan \& Jin 2015), these two types of energy analysis should gain more attention from BIM researchers in the future.

On research goals, methods, and outputs

As shown in Table A3 in Appendix, in 2007, Laine et al. (2007) presented a framework of how green BIM can benefit project stakeholders in thermal \& energy management throughout the building lifecycle. Since their work, many studies have been researching how to use different BIM authoring tools with simulation tools to perform 
energy analysis of a green building. Many of them used case studies to demonstrate and validate the effectiveness of these tools, and provided guidelines for the operation and analysis process (e.g., Krygiel \& Nies 2008, Stumpf et al. 2009, Cho et al. 2010, Kim \& Woo 2011, Shrivastava \& Chini 2012, Shoubi et al. 2015, Abanda \& Byers 2016). Others used case studies to conduct comparison between different tools, and provided guidelines in choosing the ideal tool for users (Cho et al. 2012, Reeves et al. 2012a, 2012b, Alam \& Ham 2014). A few other studies focused on how to conduct accurate modeling to conduct T\&EA correctly (e.g., Wang et al. 2013, Ryu \& Park 2016).

As shown in Table A4 in Appendix, many research studies focused on solving the interoperability problems of green BIM tools through information transition (i.e., selection, addition, translation) for T\&EA with an automatic process. Some of these studies have utilized Revit and its API to achieve data integration between BIM authoring and simulation tools and create plugins as customized assisting tools. For instance, Yan et al. (2013) and Kim et al. (2015) have developed plugins to link BIM and Object-Oriented Physical Models (in Modelica) for building thermal simulations. Jalaei and Jrade (2014a, 2014b) developed a plugin linking Revit and Ecotect for energy analysis. Besides developing plugins, Kim and Anderson (2012), Cemesova et al. (2015), Choi et al. (2016) developed programs for information transition between BIM and simulation tools. Kim and Anderson (2012) extracted information from a BIM model and compiled it into an INP file for the DOE-2 engine to conduct T\&EA, while Choi et al. (2016) turned the information into an IDF file for Energyplus. Cemesova et al. (2015) extracted geometric information from a BIM model and extended schema for the Excel-based low energy design tool Passive House Planning Package (PHPP). Besides developing programs, Chen and Das (2014) and Gupta et al. (2014) developed web service platforms to conduct analysis of operational and renewable energy of a green building. They also utilized major information exchange formats (i.e., gbXML and IFC) instead of using one specific BIM authoring tool. Chen and Das (2014) linked the uploaded gbXML file with other required information (e.g., HVAC, lighting, schedule) for conducting energy analysis with Energyplus. Gupta et al. (2014) utilized IFC and used algorithms in existing PV simulation tools to conduct solar PV simulation.

In the future, more research should be carried out on the application of open-BIM data exchange standard (i.e., IFC format) to achieve higher interoperability of green BIM tools (Chen \& Das 2014, Gupta et al. 2014). To achieve higher accuracy of T\&EA, how to overcome the limitation of existing tools on analyzing free-formed models is also a question to be answered (Kim \& Yu 2016a, 2016b). Moreover, most of the current T\&EA is conducted in a static way (i.e., completed manually by analysts). To provide timely information for designers to achieve informed decision making, a dynamic calculation of T\&EA should be accomplished by green BIM tools (Schlueter \& Thesseling 2009, Welle et al. 2011).

Other than focusing on information transition, few studies focused on information visualization and optimization of T\&EA by green BIM tools. Schlueter and Thesseling (2009) utilized Revit, its API and German Energy Savings Regulation EnEV to calculate and visualize analysis result of the energy and energy flows of a building and heating system design, resulting in an assisting tool called Design Performance Viewer (DPV). Welle et al. (2011) utilized Digital Project, its API, Energyplus and Radiance to simulate the thermal and daylighting performance. Furthermore, they used ModelCenter as the optimization graphical user interface and completed a serial of plugins to achieve better decision making in multidisciplinary design optimization (MDO) environments.

\section{On tools \& techniques}

The most utilized BIM authoring tool in the collected studies on T\&EA was Autodesk Revit (15 out of 31). This might be related to its higher interoperability with major T\&EA tools (e.g., GBS, Ecotect, IES) (Azhar \& Brown 2009). As shown in Table 2 below, Ecotect is the most utilized simulation tool in the collected papers. This might be related to its ability to import and export a range of file formats (Cho et al. 2010) and create a more intuitive design process (Crawley et al. 2005). In the future, more research should be conducted with other popular BIM authoring tools (e.g., ArchiCAD, Sketchup) and other major simulation tools. For instance, IES has been recognized by Azhar and Brown (2009) and Reeves et al. (2012a) as the best BEM tool, however, research on its application is rather limited compared to Ecotect and GBS.

Table 2. Major simulation tools used for BIM-based T\&EA in the collected papers

\begin{tabular}{|c|c|c|c|c|c|c|}
\hline T\&EA tools & Ecotect & GBS & IES & Energyplus & eQuest & DOE-2 \\
\hline Tagged times & 8 & 6 & 5 & 5 & 4 & 4 \\
\hline
\end{tabular}




\subsubsection{BIM for solar \& daylighting analysis (S\&DA)}

Analysis on the influences of environmental light includes solar analysis, shading analysis, daylighting analysis, and lighting analysis (Azhar \& Brown 2009). Solar analysis aims to quantify the amount of solar energy on a building and its site, which is critical to passive design and solar energy design. Shading analysis, also known as right-to-light analysis, is one of the key aspects of site analysis at the early project stage. Daylighting analysis is one of key indicators of indoor environmental quality in various green building rating systems. Lighting analysis refers to analysis of artificial lighting design of a building. In short, such analysis is critical to green building design for achieving higher energy efficiency and better indoor environmental quality. BIM research on S\&DA are presented in Table A5 in the Appendix and discussed in the following subsection.

\section{On detailed BPA types}

Most of the collected papers focused on green BIM application for daylighting analysis. Few papers discussed other aspects of lighting environment. More BIM study on solar, shading, and lighting analysis are to be explored.

On research goals, methods, and outputs

Some research focused on the application of green BIM tools for S\&DA and provide guidelines for the analysis process and tool selection (Krygiel \& Nies 2008, Azhar \& Brown 2009, Reeves et al. 2012a). Others focused on the development of green BIM tools for automatic information transition. For instance, Yan et al. (2013) and Kota et al. (2014) developed plugins with Revit and its API to produce the required information for Radiance and Daysim to conduct daylighting analysis. Jalaei and Jrade (2014a, 2014b) also developed plugins for daylighting analysis by Ecotect. However, further study on the capability of visualization and interpretation of the analysis result of these green BIM tools are still required.

\section{On tools \& techniques}

Revit is the most utilized BIM authoring tool for study on S\&DA. This might be related to Revit's higher interoperability with major S\&DA tools. Meanwhile, the most utilized simulation tools for S\&DA are Ecotect and Radiance. This might be related to their ability to import and export a range of file formats (Cho et al. 2010, Kota et al. 2014) and to create a more intuitive design process (Crawley et al. 2005).

\subsubsection{BIM for wind \& ventilation analysis (W\&VA)}

The wind environment of a building site is critical to create comfortable indoor and outdoor environments. With wind analysis, designers can make use of moderate wind for natural ventilation and avoid strong wind, which causes discomfort in urban environments (Lee \& Song 2010). Ventilation analysis (both natural and artificial) helps designers to provide better indoor environmental quality. Therefore, W\&VA should also be taken into consideration in the building lifecycle to ensure high indoor and outdoor environmental quality. Research progress on BIM for W\&VA is discussed in Table A6 in the Appendix and discussed in following subsections.

\section{On detailed BPA types}

BIM research on W\&VA is limited. Since the wind environment has a critical impact on indoor and outdoor environmental quality, researchers should pay more attention to BIM applications for W\&VA.

\section{On research goals, methods, outcomes}

Some researchers focused on the comparison between green BIM tools for W\&VA and provided guidance for tool selection (Azhar \& Brown 2009, Reeves et al. 2012a). Lee and Song (2010) utilized the BIM schema gbXML and the W\&VA tool DesignBuilder to demonstrate the analysis process of an outdoor wind environment to facilitate better decision making on building layout at the early project stages.

Yoon et al. (2014) utilized the BIM authoring tool Revit and the W\&VA tool scSTREAM for natural ventilation analysis of a housing project to meet the requirements of Singapore's "Green Mark" green building rating system. Following Green Mark's guidelines, a two-stage analysis process was achieved through automation of building geometric information transition and simulation setting between green BIM tools (Yoon et al. 2014).

\section{On tools \& techniques}

As mentioned in the previous paragraph, only few BIM papers researching on W\&VA. How W\&VA can be achieved with the utilization of different BIM authoring tools and formats with different simulation tools is a critical question to be answered. 


\subsubsection{BIM for acoustic analysis (AA)}

Acoustic design is important to indoor environmental quality and architectural functionality. Several green building rating systems also consider a good acoustic environment as one of the key factors for green buildings (e.g., LEED in USA, EEWH in Taiwan). However, the importance of acoustic design is often neglected in the design process (Wu \& Clayton 2013).

Table A7 in the Appendix shows the collected literature associated with AA, which is rather limited. Azhar and Brown (2009) compared three simulation tools (Ecotect, GBS, IES) based on their capacity for conducting AA via interviews with BIM and LEED experts to provide guideline for tool selection. Wu and Clayton (2013) utilized Revit as the BIM authoring tool for the extraction of geometric and component information and its API to create a plugin for the calculation, auralization, and visualization of AA to help architects to simulate acoustic effects of their design in the early stages of design projects.

Concerning future research directions of BIM for AA, utilization of different BIM authoring tools and formats with different simulation tools is a trajectory yet to be explored. Furthermore, how the adoption of green BIM tools for AA can change design processes, and how more realistic ways of auralization and visualization (such as virtual reality) can assist in simulation in real time are also potential topics to be investigated (Wu \& Clayton 2013).

\subsubsection{BIM for water efficiency analysis (WEA)}

Since water is an essential yet limited resource, water efficiency is a key aspect of green buildings, which is included in most green building rating systems around the world (e.g., LEED in the USA, BREEAM in the UK, EEWH in Taiwan). To achieve high water efficiency, architects and engineers need to take various aspects into consideration at the early stage of projects, which include elimination of water use, selection of efficient equipment, rainwater harvesting, and gray water reuse (Krygiel \& Nies 2008).

Even though the importance of water efficiency is recognized by the construction industry, as shown in Table A8 in the Appendix, only a small amount of papers discuss BIM potential in integrating water efficiency analysis into design and decision-making processes. Krygiel and Nies (2008) utilized Revit for calculation of roof area and used Microsoft spreadsheets for further calculation of rainwater reuse with climate data and overall building water loads by fixtures to calculate and optimize water harvesting. Reeves et al. (2012a, 2015) noted the available outputs of 12 BEM tools and their results showed that only five of these tools were able to conduct analysis related to water usage: eQuest, EcoDesigner, GBS, Ecotect, and EnergyPlus.

Since the importance of water efficiency is high and the potential of BIM in achieving water saving design is still largely unexplored, "blue BIM" is a critical and urgent topic for green BIM, which will benefit not only architects but also MEP engineers and landscape designers to achieve integrated green building design. The differences between existing green BIM tools in achieving water efficiency analysis and their actual benefits in empirical projects also bear close attention.

\subsubsection{BIM for lifecycle analysis (LCA)}

Lifecycle analysis (LCA) is regarded as a powerful method to assess overall environmental impacts (EIs) of building (Jrade \& Jalaei 2013). These EIs include the potential for global warming, acidification, ozone depletion, and other ill effects, which are associated with material selection. Several tools for building EI analysis under LCA frameworks (e.g., Impact Estimator) are available on the market. Utilizing LCA methods and tools at early design stages is beneficial for reducing potential EI of a building by improving decision making on material selection and structural design. The collected literature associated with LCA is presented in Table A9 in the Appendix and discussed in the following subsections.

\section{On detailed BPA types}

Several researchers utilized LCA methods and tools to analyze overall EIs of building associated with building material selection (Jrade \& Jalaei 2013, 2014a, Lee et al. 2015) and structural design (Oti \& Tizani 2015). These EIs included potential for global warming, acidification, ozone depletion, etc. (Jrade \& Jalaei 2013, 2014a, Lee et al. 2015), and ecological footprint (Oti \& Tizani 2015). However, EIs caused by other sections of a building throughout its lifecycle (e.g., building equipment, construction, and demolition activities) were overlooked. 
Several researchers focused on potential for utilizing green BIM tools for LCA. Through interviews and case studies, Azhar and Brown (2009) and Reeves et al. (2012, 2015) compared the capacity of several popular simulation tools interlinking with BIM for LCA. The results show that most of these BIM tools integrated LCA as one of their available outputs. Through a literature review, Díaz and Antón (2014) analyzed the status of LCA modeling and proposed a new framework for integrating BIM and LCA.

Other researchers focused on the development of green BIM tools, including automation of information transition, computation, and optimization for LCA. Jrade and Jalaei (2013, 2014a) utilized Revit and its API to create a plugin to link quantity take-off of a model with LCA tool Impact Estimator for assessing the design's EI. Lee et al. (2015) also utilized Revit and its API to link material quantity of a model with Korean life cycle inventory (LCI) databases to calculate the EI of a building. Oti and Tizani (2015) created another plugin with Revit API to calculate the ecological footprint of a structural design with data by Wackernagel et al. (2004) and prioritized different design options based on a multiple attribute decision-making framework.

\section{On tools \& techniques}

Our analysis result shows that BIM researchers mainly used Revit and its API with LCA methods and tools for LCA. How different BIM authoring tools and formats (e.g., IFC) can be utilized with different LCA tools for LCA at early project stages is an important question.

\subsubsection{BIM for carbon footprint assessment (CFA)}

According to Intergovernmental Panel on Climate Change (IPCC), the global temperature has increased rapidly due to the increase of greenhouse gases resulting from overuse of fossil fuels and other human activities (IPCC, 2011). Moreover, according to IPCC estimation, the building sector accounts for $40 \%$ of energy resources and $36 \%$ of carbon emissions. In response to this urgent need to mitigate global warming and climate change, governments, industry, and academia have started to promote the assessment and reduction of the carbon footprint caused by buildings (Alwan \& Jones 2014). With the help of BIM, the carbon footprint of buildings can be more easily analyzed in early project stages (Oti \& Tizani 2015). The collected literature associated with CFA is shown as Table A10 in the Appendix and discussed below.

\section{On detailed BPA types}

Many CFA studies with green BIM tools focused on the embodied carbon of building materials. Others focused on carbon produced by buildings' operational energy or on CFA in whole building lifecycles. Few focused on the carbon footprint caused by construction activity and carbon storage made by plant greening.

On research goals, methods, outcomes

Many researchers utilized green BIM tools for CFA and provided guidelines for analysis processes. Mah et al. (2011) used Virtual Construction for quantity take-off with data from the Landmark Group in Canada for CFA of housing construction. Alwan and Jones (2014) also utilized BIM for quantity take-off with data from Inventory of Carbon and Energy (ICE) in the UK for the analysis of embodied carbon by building materials. Chen and Li (2014) and Peng and $\mathrm{Wu}$ (2015) not only used Revit for quantity take-off but also for conducting energy analysis to perform CFA for whole building lifecycles. At the end of their case study, Chen and Li (2014) used a compromise decision model to show how to achieve optimal decision making on building material selection. Peng and $\mathrm{Wu}$ (2015) conducted sensitivity analysis to identify the crucial factors associated with building's carbon footprint. Reeves et al. $(2012,2015)$ research showed that most of the BEM tools considered (11 out of 12) included CFA as one of their available outputs.

In addition to the application of green BIM tools, other researchers focused on further development of these tools for CFA. For example, Li et al. (2012) linked Revit with the database of a carbon calculation software package (BEES) and created a plugin to calculate the real-time carbon emissions of a building. Chen and Hsieh (2013) also created a plugin with Revit and its API for calculation of carbon storage of plant greening under the Taiwanese green building code for both automatic rule-checking of green building design and real-time visualization of feedback. Besides automation of data computation, Bank et al. (2011) linked the system dynamics modeling program (AnyLogicTM) for optimization of design decision making. Lu et al. (2015) used C++ to create a program with Fuzzy RPOMETHEE method for multi-criteria decision making. 


\section{On tools \& techniques}

Most researchers utilized Revit as the BIM authoring tool for their CFA studies. There should be more study on applications of other authoring tools or information exchange formats to enhance interoperability of green BIM tools for CFA. Furthermore, how the existing simulation tools can be incorporated with BIM tools to assist CFA during the design process is still a topic to be discussed. In addition, due to the lack of information about the carbon footprint of local materials, most existing simulation tools only conduct CFA by considering buildings' operational energy. Therefore, many researchers used API to customize new applications of BIM tools to fill this gap. In the future, how information on local building materials can be merged with BIM tools to conduct more comprehensive CFA is an urgent issue to be addressed.

\subsubsection{BIM for cost and benefit analysis (CBA)}

According to McGraw-Hill's (2013) report, higher initial cost is regarded as the most significant barrier for current development and future growth of green building. Hence, cost estimation, control and benefit analysis throughout project stages become critical to the success of green building projects. By providing one source for cost estimation for an entire project lifecycle, BIM can achieve high accuracy from front-end cost budgeting to building construction cost (Forgues et al. 2012). The collected literature associated with CBA are shown as Table A11 in the Appendix and discussed below.

On detailed BPA types

The collected research on CBA considered six types of building cost: building life cycle cost (BLCC), building energy life cycle cost (BELCC), hard cost, soft cost, demolition cost, and carbon tax. Hard cost here refers to the construction cost of a green building, while soft cost refers to registration and certification fees for green buildings (Jalaei \& Jrade 2015). BELCC refers to life cycle expense on operational energy, while BLCC includes the hard cost of a green building and also BELCC or other building operation and maintenance costs. Demolition cost involves the expense associated with destruction and waste management. Carbon tax refers to additional expenses charged according to building carbon emissions.

Among these types of building cost, BLCC and hard cost of a green building are the more discussed (7 and 3 out of 16 respectively). BELCC and demolition cost also raised some attention among research groups. Soft cost and carbon tax are new types of green building costs addressed by the researchers.

On research goals, methods, outcomes

Some research teams focused on the application of green BIM tools for CBA. According to Reeves et al. (2015), 10 out of 12 green BIM tools can be used to analyze BELCC, and Azhar and Brown (2009) concluded that IES is the most ideal tool for CBA (compared with GBS and Ecotect). Kabassi and Cho (2012) also utilized simulation tools to analyze BELCC of their zero-net-energy home. Besides BELCC, they used a BIM authoring tool for quantity take-off to estimate costs of green building materials in order to conduct CBA of green building technologies. In a similar vein, Chen and Li (2014) used Revit and eQuest for quantity take-off and energy simulation to estimate BLCC and carbon emissions and achieve optimal decision making.

Some other researchers focused on further development of green BIM tools for CBA. Most researchers in this group utilized a BIM authoring tool and its API to create customized plugins to calculate green building costs automatically. They took advantage of BIM capacity in quantity take-off to estimate hard cost (e.g., Jrade \& Jalaei 2013, Jalaei \& Jrade 2014a, 2014b), operation and maintenance cost (e.g., Marzouk et al. 2013, 2014, Oti \& Tizani 2015), demolition cost (e.g., Cheng \& Ma 2013, Akbarnezhad et al. 2014), and soft cost (Jalaei \& Jrade 2015) of a green building. Besides these customized plugins, Chen et al. (2013) and Lu and Lee (2015) proposed frameworks of CBA processes with green BIM tools and information needed for automatic computation. Dawood (2016) also proposed a framework for optimal life cycle cost of sustainable houses by integrating BIM and Genetic Algorithm.

Despite these efforts in creating customized tools and proposing process frameworks, a more comprehensive BIM tool that provides simultaneous analysis of various types of green building costs and benefits is still missing at present, hindering designers in seeing the true value of their design throughout their projects' various stages. 


\section{On tools \& techniques}

Most researchers utilized Revit and its API to create customized plugins for CBA. Few saw potential in Telka and the IFC format. Nevertheless, there should be more study on other authoring tools or information exchange formats to enhance interoperability of green BIM tools for CBA.

Several building energy modeling tools (e.g., GBS, Ecotect, IES) were utilized to simulate operational energy and estimate energy cost for CBA. Although there are many cost estimators integrated with BIM tools available on the market (Eastman et al. 2011), they are not utilized by green BIM researchers for CBA. This might be due to the lack of databases for local green building materials and technologies. Therefore, there is an urgent need for these cost estimation tools or sustainability analysis tools to be integrated with information related to green building costs and benefits for CBA to achieve optimal decision making.

\subsubsection{BIM for green building rating analysis (GBRA)}

Several green building rating systems (GBRS) have been developed worldwide since 1990 to evaluate building sustainability for promotion of green building (Zuo \& Zhao 2014). Current leading systems include: BRE Environmental Assessment Method (BREEAM, UK), Leadership in Energy and Environmental Design (LEED, USA), Green Star (Australia), Green Mark (Singapore), Building Environmental Assessment Method (BEAM, Hong Kong). These systems have been developed according to local climatic conditions and building regulations. Therefore, their assessment criteria and methods vary. However, they all share a similar structure covering various aspects of building sustainability. Their key aspects are: building energy consumption, water efficiency, material use, and indoor environmental quality.

One of the significant challenges posed for the adoption of GBRS is the cost and length of time required for certification (McGraw-Hill 2013). Early evaluation of green building projects with these systems can prevent the inefficient process of retroactive modification to the design and reduce risk of failure in gaining certification (Robichaud \& Anantatmula 2010). A building information model carries a wealth of multi-disciplinary information, which enables rating analysis to take place from the early design stage, and can produce necessary documentation efficiently for earning credits (Azhar et al. 2011).

Researchers around the world have recognized the potential of BIM in assisting rating analysis for green building certification with local GBRS. Their studies on GBRS with BIM are divided into two groups in this study according to the GBRS studied and by the amount of papers collected: LEED (18) and other GBRS (16). The former group is studied in next section and shown as Table A13 in Appendix, while the latter is covered in this section and shown as Table A12. These papers were also noted with their research features and discussed as follows.

\section{On detailed BPA types}

Table 3 shows how many times different GBRS were studied in the collected papers. LEED from the USA is the most studied GBRS. BREEAM from (UK), Green Star (Australia), EEWH (Taiwan), Green Mark (Singapore), and BEAM (Hong Kong) comprise the second tier. Six other GBRS that have attracted limited attention. This result might be related to the adoption rates of GBRS and BIM in different countries. Moreover, several leading GBRS are neglected by BIM researchers at present (e.g., DGNB from Germany). As the needs for green building and BIM adoption are increasing continually (McGraw-Hill 2010), more research on how BIM can assist in rating analysis with different GBRS should be carried out to upgrade the construction industry worldwide.

On research goals, methods, outcomes

Some researchers focused on the application of green BIM tools for GBRA. Many of them aimed to propose frameworks for the integration of BIM and GBRS in their countries (e.g., BREEAM from the UK, Green Star from Australia, BEAM from Hong Kong). Most of them achieved this goal through a series of interviews with local experts in green BIM (e.g., Gandhi \& Jupp 2014, Wong \& Kuan 2014, Zanni et al. 2014). Other than proposing BIM frameworks for local GBRS, Solla et al. (2016) compared the "BIM potential" of integration with three leading GBRS: LEED, Green Star, and BEAM. Through their research, two crucial research questions have been raised: (1) How can BIM tools be improved to increase higher potential of integration with GBRS? (2) How can GBRS be upgraded with more quantitative evaluation methods for higher potential of BIM application? 
Table 3. The number of times different GBRS were studied in the collected papers

\begin{tabular}{|l|l|r|}
\hline Green Building Rating System & Country & No. \\
\hline LEED & USA & 18 \\
\hline BREEAM & UK & 4 \\
\hline Green Star & Australia & 3 \\
\hline EEWH & Taiwan & 3 \\
\hline Green Mark & Singapore & 2 \\
\hline BEAM & Hong Kong & 2 \\
\hline Green Globes & USA & 1 \\
\hline Super Building & EU & 1 \\
\hline CASBEE & Japan & 1 \\
\hline G-SEED & South Korea & 1 \\
\hline GBI & Malaysia & 1 \\
\hline SAGRS & Saudi Arabia & 1 \\
\hline
\end{tabular}

The other group of researchers focused on the development of green BIM tools for GBRA. Some researchers proposed frameworks of information transition and computation process (e.g., Jun et al. 2015, Raffee et al. 2016), while others developed customized plugins and programs for their GBRA (e.g., Chen \& Hsieh 2013, Wu \& Chang 2013, Chandra \& Zhou 2014, Yoon et al. 2014, Marzouk et al. 2014, Ilhan \& Yaman 2016).

It is worth noting that many researchers in this group recognized the importance of establishing essential properties and databases for BIM objects and the strength of BIM tools in scheduling and material take-off for GBRA. For instance, Ilhan and Yaman (2016) created a green material database and library under the BREEAM scheme, added related information to model under the IFC scheme, and created a program to compute material take-off and rating score for BREEAM materials. Likewise, Marzouk et al. (2014) adopted a similar framework under the Saudi Arabia Green Building Rating System (SAGRS) for the selection of optimum sustainable building materials that was developed, expanding the features of BIM technology.

Besides evaluation of building materials and resources, Chen and Hsieh (2013) added extra attributes to building objects (trees) for automatic rule-checking of green building design under the Taiwanese GBRS-EEWH scheme. Wu and Chang (2013) also added extra attributes to building objects of models and captured their quantity with BIM tools for the calculation of Req result as an indicator for energy saving in EEWH. Even though scheduling and material take-off are strong features of BIM tools, Chandra and Zhou (2014) identified their potential errors. Hence, they utilized XML format and created a new add-on for further modeling, setting, and fine-tuning, and for the automation of Concrete Usage Index (CUI) calculation under Singapore's Green Mark system.

In addition to computing and calculating rating scores for GBRS, BIM tools are proven to be able to accelerate the certification process via more efficient documentation processes. Following Green Mark's guideline for natural ventilation analysis, a two-stage analysis process was achieved through the automation of building geometric information transition and simulation setting between green BIM tools (Yoon et al. 2014).

\section{On tools \& techniques}

This group of researchers used different BIM authoring tools (e.g., Revit, Telka, ArchiCAD, Bentley) and information exchange formats (e.g., IFC, gbXML) for their GBRA study. This is beneficial for the increase of interoperability between green BIM tools, which should be encouraged in future research as well.

Concerning simulation tools for GBRA, it is known that several tools on the market advertise their ability to conduct GBRA (e.g., IES for BREEAM). However, utilization of such tools for GBRA throughout green building projects has not yet been discussed by researchers, which brings about the need for further investigation to identify their strengths and weaknesses for further improvement and best practice. 


\subsubsection{BIM for LEED rating analysis (LEEDRA)}

Leadership in Energy and Environmental Design (LEED) is a green building rating system (GBRS) developed by the United States Green Building Council (USGBC) in 1998 to evaluate the environmental performance of a building and encourage market transformation toward sustainable design. To date, there are more than 89,600 projects participating in LEED across 164 countries and territories worldwide (USGBC 2017). LEED has become one of the most popular and influential GBRS in driving international green building practices.

Even though LEED is regarded as a powerful tool, its certification process is challenging and tedious. To streamline this process, USGBC has launched a web-based platform called LEED Online in 2006 to help project teams to manage LEED documentation (USGBC 2014). However, it holds a major bottleneck, which originates from its intrinsic deficiency of traditional project delivery method: fragmentation induced by lack of interoperability (Wu \& Issa 2011). Since a building information model carries a wealth of information, it may be utilized to produce the necessary documentation for earning LEED credits more efficiently (Azhar et al. 2011). BIM researchers' efforts in exploring BIM potential for LEEDRA are recognized in this study. Eighteen relevant papers are analyzed with their research features, shown as Table A13 in the Appendix, and discussed below.

\section{On detailed BPA types}

LEED contains five key categories: sustainable site (SS), water efficiency (WE), energy \& atmosphere (EA), materials \& resources (MR), and indoor environmental quality (IEQ). Each category contains prerequisites and credits. Based on the number of credits achieved, a project can be certified with different LEED rating levels.

The LEED categories studied in the collected papers are further analyzed as shown in Table 4. MR and EA are the two most discussed categories by BIM researchers. This might be related to the strengths of current BIM tools in material take-off and thermal \& energy analysis. Even though SS category has the second most credits in the LEED system (e.g., 26 out of 110 credits in LEED NC version 2009), little discussion has been made on how to utilize BIM in assisting LEEDRA in this category. This might be associated with the types of information this category requires for documentation, which are more qualitative and related to geographic information, and are more difficult to gain with current BIM tools. Besides SS, WE and IEQ categories also receive limited attention from BIM researchers. More research needs to be carried in the near future exploring BIM potential in assisting LEEDRA on these three categories.

Table 4. The number of times different LEED categories were studied in the literature

\begin{tabular}{|l|r|}
\hline Categories of LEED & Times \\
\hline all/ general & 7 \\
\hline Sustainable Site (SS) & 2 \\
\hline Water Efficiency (WE) & 2 \\
\hline Energy \& Atmosphere (EA) & 6 \\
\hline Materials \& Resources (MR) & 8 \\
\hline Indoor Environmental Quality (IEQ) & 1 \\
\hline
\end{tabular}

\section{On research goals, methods, outcomes}

As shown in Table A13, the collected papers related to LEEDRA are divided by their research goals: focusing on application or development of green BIM tools. Regarding the former group, several researchers proposed frameworks of BIM and LEED integration via reviews and case studies: Biswas et al. (2008) offered a general framework to capture broad categories of LEED and other GBRS, and a system architecture for sustainable building information modeling (SBIM). Azhar et al. (2011) offered a conceptual framework to identify the relationship between BIM and the LEED rating process. They identified that up to 17 LEED credits and 2 prerequisites can be gained using results generated by BIM tools, while Solla et al. (2016) identified 38 LEED credits achievable with BIM tools. Besides these frameworks, Wu and Issa (2014) proposed a BIM execution plan for a LEED project through a series of interviews.

In addition to these frameworks, some researchers provided guidelines for the analysis process of LEEDRA using existing BIM tools with case studies. Krygiel and Nies (2008) utilized Revit and simulation tools (e.g., eQuest, IES) to perform analysis related to WE, EA, and IEQ credits in LEED, while Barnes and Castro-Lacouture 2009 
demonstrated methods to perform analysis for SS and MR credits. Some others provided guidelines to select BIM tools for LEEDRA. Reeves et al. (2015) identified that 6 BEM tools out of 12 provide LEED credit assistance.

As mentioned above, the other group of researchers focused on the development of green BIM tools by creating customized plugins for LEEDRA. Many of them recognized the potential of BIM tools in assisting LEEDRA for the MR category and emphasized the importance of establishing green building material databases (Bank et al. 2011, Jrade \& Jalaei 2013, Jalaei \& Jrade 2014a, 2014b, Marzouk et al. 2013). Meanwhile, some saw the strengths of simulation tools in LEED RA for the EA category and tried to combine them into one integrated tool (Jalaei \& Jrade 2014a, 2014b). Besides the MR and EA categories, Chen and Nguyen (2015) utilized Revit and its API to integrate geographic information with BIM to improve the efficiency of LEED's location and transportation analysis for the SS category. In addition to rating analysis, Jalaei and Jrade (2015) included cost analysis of construction and certification cost for LEED projects and created a plugin for automatic calculation.

In addition to these customized plugins, some other research proposed frameworks for further development of green BIM tools in assisting LEEDRA throughout project stages. Wu and Issa (2011) stated the limitations of current online documentation tools and offered a new framework of BIM-facilitated web service for LEED automation. Zhang et al. (2014) and Zhang and Chen (2015) saw the potential of the new technology "RTLS" with BIM and proposed a framework for lifecycle evaluation of building sustainability using BIM and RTLS. Both these frameworks, which adopted new technologies for LEEDRA, require further case studies for validation in future.

\section{On tools \& techniques}

Most of the BIM researchers who studied LEEDRA utilized Revit as their authoring tool. This might be because that most of the researchers who studied LEEDRA were USA-affiliated and Revit is the most popular BIM authoring tool in the USA. (Sattineni 2011). Some simulation tools have been used by researchers in this group mostly for energy performance analysis. It is known that Revit has developed a tool for LEEDRA called Revit Credit Manager for LEED, which includes credit analysis for WE, MR, and IEQ categories (Autodesk 2014). However, how this tool can be utilized for LEED projects is still unknown and needs further exploration.

\section{On case study building types}

Housing, school, and office were the three building types tested most commonly for LEEDRA with BIM, yet the differences in LEEDRA between different building types were rarely mentioned in the collected BIM research. Nowadays, most GBRS have developed various versions for different building and project types. For example, LEED differentiates building types including New Construction, Core and Shell, Schools, Retail, Data Centers, Warehouses and Distribution Centers, Hospitality, and Healthcare. How to reflect such differences for different projects and building types in LEEDRA with BIM is another question for BIM researchers to consider.

\subsection{Synergized analysis}

\subsubsection{Integrated design analysis (IDA)}

Green building design is a multi-disciplinary science that requires integral thinking to achieve optimal decision making (Krygiel \& Nies 2008). Therefore, adopting multiple types of building performance analysis (BPA) in the early design stage is critical to the outcome of a green building project. Even though this paper is discussed by different BPA types in the previous sections, a synergized discussion on integrated design analysis is proposed here.

Among the 80 green BIM papers collected, 21 examined more than one BPA type. This indicates that now most of the green BIM research has been focused on one specific type of BPA. How to utilize BIM to conduct IDA is still being explored. In the future, more studies with multiple BPA types with BIM are expected.

Furthermore, several BPA types have shown a tendency to be grouped together for IDA. For instance, many studies (e.g., Welle et al. 2011, Yan et al. 2013, Gupta et al. 2014) conducted both T\&EA and S\&DA. This might be because providing a good thermal and lighting environment is the most noticeable challenge for envelope design (Krygiel \& Nies 2008). Nevertheless, to provide a good outdoor and indoor environment, not only T\&EA and S\&DA but also W\&VA and AA should be considered together. For instance, considering both ventilation and acoustic environment is important for HVAC design, and should be studied more by BIM researchers in the future. Since the feature of BIM is to integrate information in modeling, more analysis of environmental qualities can be conducted together in a more efficient way. 
Besides analysis of environmental quality, several studies (e.g., Oti \& Tizani 2015, Chen \& Li 2014, Lu \& Lee 2015 ) conducted both CFA and CBA with BIM. This might be because climate change and economic sustainability have gained much attention in recent years. Moreover, since quantity take-off is one of the main features of BIM, LCA, CFA, and CBA can be carried out more easily together, which should not be neglected for IDA. Finally, several studies (e.g., Ryu \& Park 2016, Wu \& Chang 2013, Chen \& Huang 2016) combined both T\&EA and GBRA. This might be because energy efficiency is the key indicator for GBRS. Since water efficiency is also another key indicator for GBRS, study on both WEA and GBRA should be carried out in future.

Among these 21 papers, Azhar and Brown (2009) and Reeves et al. (2012a) discussed the most BPA types with green BIM tools by identifying their capabilities in conducting different types of BPA to provide guidelines for tool selection. However, they only identified these capabilities of green BIM tools, but did not demonstrate how to use them all in real cases. Therefore, more study should be made on how to use these tools in empirical projects for IDA to evaluate green building design in a more comprehensive and effective way.

\subsubsection{Other building performance analysis types}

Besides these ten key BPA types that have been highlighted in this study, there are other important aspects of green building, which have been overlooked by green BIM researchers to date. For instance, ensuring biodiversity on building sites is one important mission of green building and has been included in many green building rating systems worldwide, yet there is very little discussion on how BIM can integrate such analysis in the design process. Furthermore, social sustainability has received more and more attention from green building researchers and councils around the world nowadays (Zuo \& Zhao 2014). How BIM can benefit the evaluation of social aspects of building sustainability is another major research question to be answered.

\subsubsection{Overall analysis on research features}

Conclusively, an overall analysis of the collected papers on their research features (including research goals, methods, outputs, tool \& technique) is carried out and discussed in the following sections to have more synergized picture of the current development of green BIM research.

\section{On research goals and outputs}

As shown in Fig 6, 41\% of the collected papers focus on green BIM tool application while the other $59 \%$ focus on tool development. This shows that in general, existing green BIM tools are still limited therefore research needs for more expansion are still on going. Among research focusing on tool application, most of them investigate how existing tools can be used to achieve BPA, while few study on how BIM can help in data integration for BPA. However, whether the existing tools can create ideal visualization and documentation for project teams has been sparsely discussed. Meanwhile, among research focused on tool development, most investigate how to automatically transit information between green BIM tools while some research on how to compute analysis beyond existing tools. Few others study on how to optimize and visualize their green building design and create documentation with the tools they have created. Through these studies, the capacity of green BIM is expanded.

Research outputs of the collected papers can be categorized into the following types: framework (e.g., for integration of information and systems), guideline (e.g., for analysis process, tool selection, modeling), plugin, program, and web service. The first two types can be regarded as soft outputs, and the other three as hard outputs.

As shown in Fig 7, 57\% of the collected papers resulted in soft outputs, while the rest produced hard outputs. As mentioned earlier in this section, even though $59 \%$ of collected papers focusing on green BIM tool development, only $43 \%$ of them resulted in hard outputs. Therefore, more research efforts should be made to realize these theoretical ideas for green BIM tool development. Moreover, among the hard outputs, most of them are plugins and few are programs and web services. As web service is gaining more attention these days for the increase of BIM interoperability (e.g. Chen \& Das 2014), there should be more research studying its possibility for the development of green BIM. 


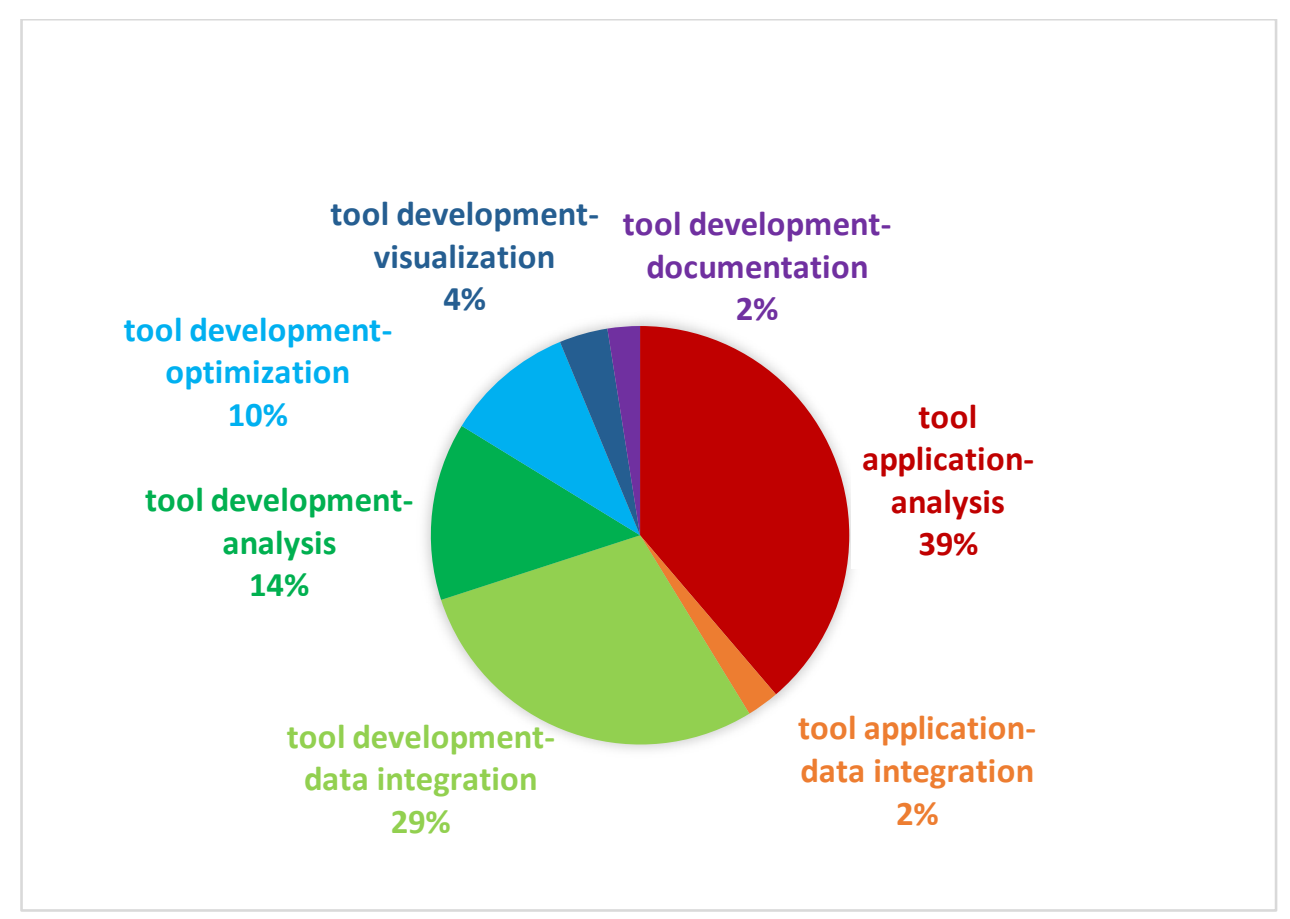

Fig 6. Green BIM papers by research goals

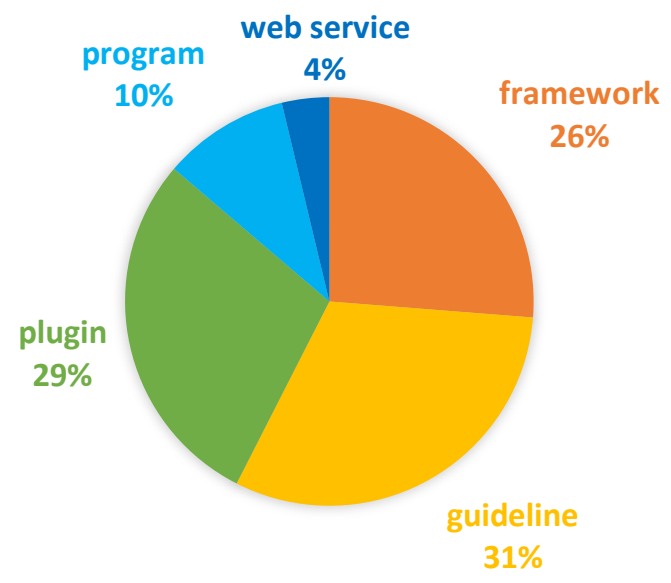

Fig 7. Green BIM papers by research outputs

On research methods and case study building types

Research methods of the collected papers can be categorized into three basic ways: via literature review, interview, or case study. Most of the collected papers, either focusing on green BIM tool application or development, utilized case studies $(73 \%)$ to validate their ideas, which is beneficial for industry sectors to learn from their practices. However, there are limited papers conducting interviews or surveys with empirical professionals in green BIM, which provides limited insight of current development and barriers empirically. This need should be recognized. 
Concerning case study building types, housing (43\%), office (23\%), and school (10\%) are the three most studied ones. As the goal of zero-carbon housing is imposed by many governments around the world (Cho et al. 2010), green BIM research on housing can provide solutions to such challenges. However, at present many other building types are infrequently discussed by green BIM researchers (e.g., hospital). This research gap should be filled.

On tools \& techniques

Concerning BIM authoring tools studied in the collected papers, as shown in Fig 8, most researchers utilized Revit. This might be related to its higher interoperability with simulation tools and user-friendly API. To increase interoperability of green BIM, how other BIM authoring tools can be utilized for BPA requires further investigation.

As mentioned in the literature review section, information exchange format (IEF) is another tool to increase interoperability of BIM. IFC, a public and non-proprietary IEF for open BIM, is utilized nine times in the collected papers, while gbXML, a popular IEF between CAD and energy analysis software, is studied four times. The amount of study on IEF is still limited and should be enhanced.

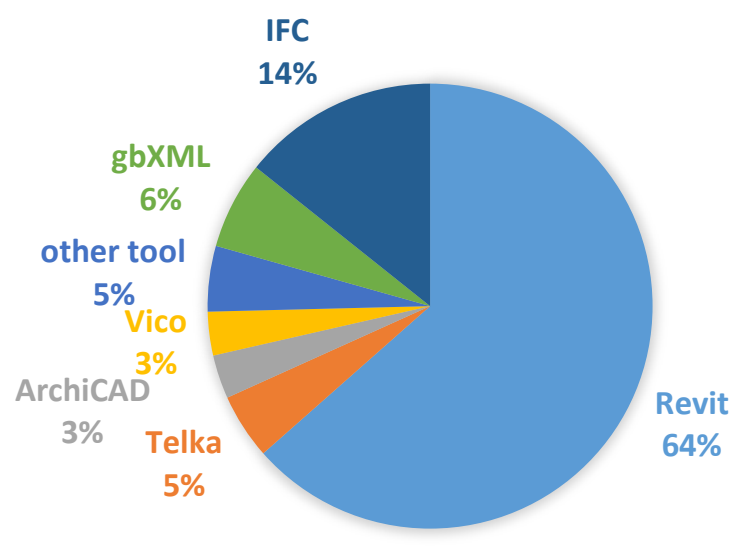

Fig 8. Green BIM papers by authoring tools

To develop customized tools, researchers utilized several programing tools. As shown in Fig 9, Application Programing Interface (API) of BIM authoring tools (e.g., Revit) is the most used programing tool, while Visual Basic for Applications (VBA) the second. Besides API and VBA, C\#, Java, and Dynamo are also utilized by researchers. These studies are all good demonstrations of how green BIM can be developed. As more programing tools being developed these days for BIM (e.g., Dynamo for Revit), the capacity of green BIM can be expanded.

To conduct BPA with BIM, several simulation tools are utilized. Most of the simulation tools are used for T\&EA, even though some of them can be used to conduct many types of BPA. Among these simulation tools, as shown in Fig 10, Ecotect (18\%), IES (11\%), GBS (9\%), and eQuest (9\%) were the most-used tools in the collected green BIM papers, followed by Energy Plus (5\%), DOE-2 (5\%), and Radiance (5\%). This might be related to Ecotect's higher interoperability with BIM and wider range of BPA. How interoperable these simulation tools are with BIM still requires more systematic study. Furthermore, how these simulation tools can be used to conduct integrated design analysis with BIM still needs further exploration. 


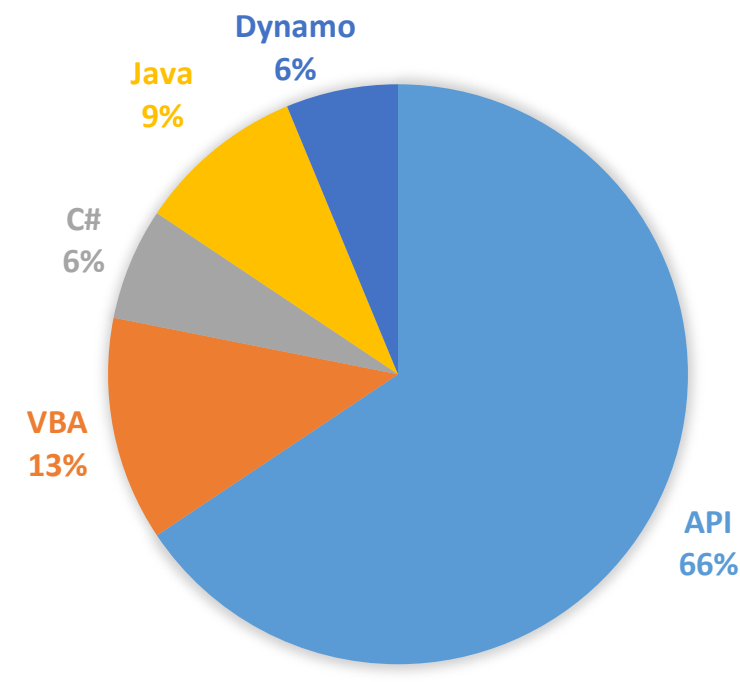

Fig 9. Green BIM papers by programing tools

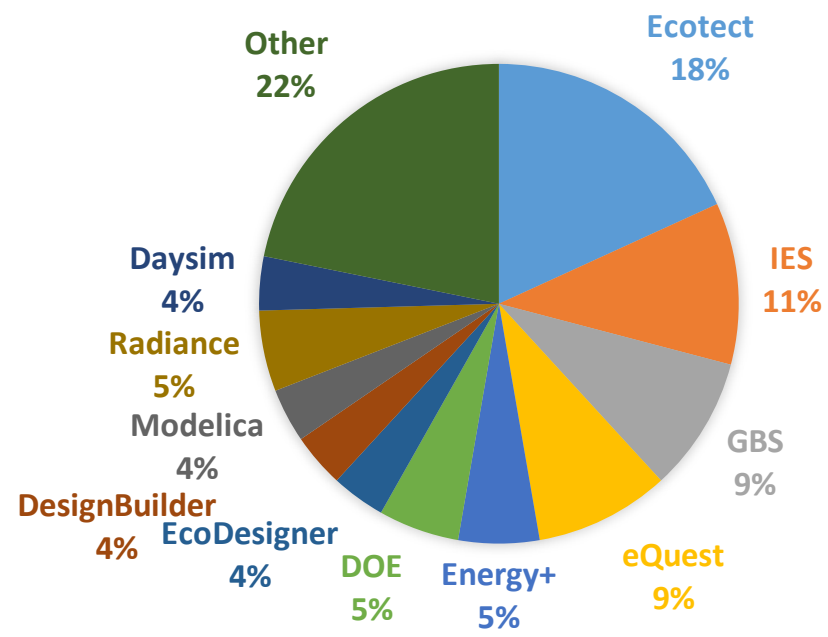

Fig 10. Green BIM papers by simulation tools

\section{DISCUSSION \& CONCLUSION}

The purpose of this study is to provide insights on current progress and future potential of BIM research for green building design through building performance analysis (BPA). Research features of the 80 collected publication are analyzed and discussed, which include ten key BPA types and five main BIM uses as research goals, methodology and tool \& technique as research method, etc. The following are the key research findings of this study:

- Concerning BPA types, thermal \& energy analysis (T\&EA) is the most discussed type. Green building rating analysis (GBRA) and LEED rating analysis (LEEDRA) are the second most discussed types of analysis. Cost-benefit analysis (CBA) and carbon footprint analysis (CFA) are also popular research topics. Even though indoor environmental quality and water resources have been recognized as important, BIM research on ventilation, acoustic, and water efficiency analysis are scarce. These are critical topics 
to be researched in the future. In Lu et al. (2017) work, they also identified research for water conservation and indoor air improvement is limited. However, they did not include CBA into their research scope thus have missed to recognize its importance.

- Concerning integrated design analysis (IDA), only about quarter of the collected papers examine more than one BPA type. This indicates that at present, most of the green BIM research has focused on one specific type of BPA. In the future, more studies on multiple BPA types with BIM are expected. Lu et al. (2017) work also supports this awareness,

- Concerning other potential BPA types, biodiversity and social sustainability are two important aspects of green building (Zuo \& Zhao 2014) that have gained much attention from green building researchers, yet have been overlooked by green BIM researchers. These areas should be taken into consideration. This finding is original from other works.

- Concerning research focus, $41 \%$ of the collected papers focused on green BIM tool application while the rest $59 \%$ focused on tool development. This shows that in general, existing green BIM tools are still limited therefore research needs for more expansion are still on going. This analysis is original from other works.

- Concerning BIM uses, among the tool application group, most of them focus on studying the analysis capability of green BIM tools. Among the tool development group, most of them focus on expanding the capability of data integration, and some on design analysis and optimization of green BIM. However, how their capability in information visualization and documentation benefits green building design still requires further investigation. This discussion is original from other works.

- Concerning research outputs, $58 \%$ of the collected papers resulted in soft outputs (i.e., frameworks and guidelines), while the rest $42 \%$ produced hard outputs (i.e., plugins, programs, and web services). This shows that some research that focused on tool development did not result in hard outputs. More research efforts are made to realize current theoretical works. This analysis is original from other works.

- Concerning research methods, majority of the collected papers utilized case studies to validate their ideas, which is beneficial for industry sectors to learn from their own practices. However, interviews or surveys with empirical professionals on green BIM tools are limited, which provides limited insight into current development and barriers. This need should be recognized. This discussion is original from other works.

- Concerning case study building types, housing, office and school are the studied more. However, some other types which are energy demanding (e.g. hospital) need more attention. This finding is original from other works.

- Concerning BIM authoring tools, most researchers utilized one main software package on the market. To increase interoperability of green BIM tools, how other BIM authoring tools can be utilized for BPA requires further investigation. Concerning information exchange formats (IEF), IFC is merely utilized nine times while gbXML four times in the collected papers. The amount of study on IEF is still limited and should be enhanced for higher interoperability. Lu et al. (2017) work also identified this situation.

- Concerning simulation tools, Ecotect, IES and GBS are the most utilized ones. How interoperable these simulation tools are with BIM still requires more testing. Furthermore, how these simulation tools can be used for integrated design analysis with BIM still needs more examination. Azhar and Brown (2009) and Reeves et al. $(2012,2015)$ works correspond to this problem.

Compared with the more general analyses on green and BIM features of existing literature by other review works (e.g. Wong \& Zhou 2015, Lu et al. 2017), this research provides more in-depth analyses on BIM research for green building design through BPA. More BPA types are included into analyses in this study, and more detailed analyses on BIM research for each BPA type are provided. Moreover, other research features like research method and output, tool \& technique are included into notations in order to have more systematic and comprehensive insights on green BIM research. This framework can also be utilized in the future to keep a clear track on this research body. Furthermore, more quantitative and visualized results are shown in this study for better presentation and more support to research findings.

\section{REFERENCES}

Abanda, F. H., \& Byers, L. (2016). An investigation of the impact of building orientation on energy consumption in a domestic building using emerging BIM (Building Information Modelling). Energy, 97, 517-527. 
Akbarnezhad, A., Ong, K. C. G., \& Chandra, L. R. (2014). Economic and environmental assessment of deconstruction strategies using building information modeling. Automation in Construction, 37, 131-144.

Alam, J., \& Ham, J. J. (2014). Towards a BIM-based energy rating system. In Proceedings of the 19th Conference on Computer-Aided Architectural Design Research in Asia, Kyoto, Japan, 285-294.

Alwan, Z., Greenwood, D., \& Gledson, B. (2015). Rapid LEED evaluation performed with BIM based sustainability analysis on a virtual construction project. Construction Innovation, 15(2), 134-150.

Alwan, Z., \& Jones, P. (2014). The importance of embodied energy in carbon footprint assessment. Structural Survey, 32(1), 49-60.

Autodesk (2014). Revit Credit Manager for LEED. Retrieved 2017-01-26. http://autodesk.typepad.com/bpa/2014/12/revit-credit-manager-for-leed-updated-try-it-now.html

Azhar, S., \& Brown, J. (2009). BIM for sustainability analyses. International Journal of Construction Education and Research, 5(4), 276-292.

Azhar, S., Carlton, W. A., Olsen, D., \& Ahmad, I. (2011). Building information modeling for sustainable design and LEED ${ }^{\circledR}$ rating analysis. Automation in construction, 20(2), 217-224.

Bank, L. C., Thompson, B. P., \& McCarthy, M. (2011). Decision-making tools for evaluating the impact of materials selection on the carbon footprint of buildings. Carbon Management, 2(4), 431-441.

Barnes, S., \& Castro-Lacouture, D. (2009). BIM-enabled integrated optimization tool for LEED decisions. In Proceedings of the 2009 ASCE International Workshop on Computing in Civil Engineering, Austin, TX, 258-268.

Biswas, T., Wang, T. S., Krishnamurti, R. (2008). Integrating sustainable building rating systems with building information models. CAADRIA 2008, 193-200.

Bynum, P., Issa, R. R., \& Olbina, S. (2012). Building information modeling in support of sustainable design and construction. Journal of construction engineering and management, 139(1), 24-34.

Cemesova, A., Hopfe, C. J., \& Mcleod, R. S. (2015). PassivBIM: Enhancing interoperability between BIM and low energy design software. Automation in Construction, 57, 17-32.

Chandra, D., \& Zhou, N. (2014). BIM Add-on Tool for Automated CUI Calculation. In Proceedings of the 19th Conference on Computer-Aided Architectural Design Research in Asia, Kyoto, Japan, 305-314.

Chen., J.Y. \& Huang, S.C. (2016). Adaptive Building Facade Optimisation: An integrated Green-BIM approach. In Proceedings of the 21st Conference on Computer-Aided Architectural Design Research in Asia, Melbourne, Australia, 259-268.

Chen, L., \& Pan, W. (2015). A BIM-integrated Fuzzy Multi-Criteria Decision Making Model for Selecting LowCarbon Building Measures. Procedia Engineering, 118, 606-613.

Chen, P. H., Chan, L., \& Chen, Y. Y. (2013). A BIM-based framework for selection of cost-effective green building design. In Proceedings of the 13th East Asia-Pacific Conference on Structural Engineering and Construction (EASEC-13), Sapporo, Japan, E-3-2, 1-7.

Chen, P. H. \& Li, Y. C. (2014). BIM-based integration of carbon dioxide emission and cost effectiveness for building in Taiwan. Society for Social Management Systems Internet Journal. 2014-12.

Chen, P. H., \& Nguyen, T. C. (2015). Integration of Building Information Modeling (BIM) and LEED's Location and Transportation Category. In Proceedings of the 32nd International Symposium on Automation and Robotics in Construction, Oulu, Finland, 1-3.

Chen, Y.W., \& Hsieh, S. H. (2013). A BIM assisted rule based approach for checking of green building design. In Proceedings of the 13th International Conference on Construction Applications of Virtual Reality, London, United Kingdom, 47-55.

Cheng, J. C., \& Das, M. (2014). A BIM-based web service framework for green building energy simulation and code checking. ITcon, 19, 150-168. 
Cheng, J. C., \& Ma, L. Y. (2013). A BIM-based system for demolition and renovation waste estimation and planning. Waste management, 33(6), 1539-1551.

Cho, C. S., Chen, D., \& Woo, S. (2012). Building information modeling (BIM)-Based design of energy efficient buildings. Journal of KIBIM, 2(1), 1-6.

Cho, Y. K., Alaskar, S., \& Bode, T. A. (2010). BIM-integrated sustainable material and renewable energy simulation. In Proceedings of the Construction Research Congress, Banff, Alberta, Canada, 2, 288-297.

Choi, J., Shin, J., Kim, M., \& Kim, I. (2016). Development of openBIM-based energy analysis software to improve the interoperability of energy performance assessment. Automation in Construction, 72, 52-64.

Chong, H. Y., \& Wang, X. (2016). The outlook of building information modeling for sustainable development. Clean Technologies and Environmental Policy, 1-11.

Cooper, H. M. (1988). Organizing knowledge syntheses: a taxonomy of literature review. Knowledge Society, 1, $104-126$.

Crawley, D., Hand, j., Kummert, M., \& Griffith, B. (2005). Contrasting the Capabilities of Building Energy Performance Simulation Programs. Joint report: U S department of energy, University of Strathclyde, Univ. of Wisconsin and NREL, 1.

Dawood, M. H. (2016). BIM based optimal life cycle cost of sustainable house framework. In Proceedings of the 3rd MEC International Conference on Big Data and Smart City, Muscat, Oman, 1-5.

Díaz, J., \& Antón, L. Á. (2014). Sustainable construction approach through integration of LCA and BIM tools. In Proceedings of 2014 International Conference on Computing in Civil and Building Engineering, Orlando, Florida, United States, 283-290.

Ding, L., Zhou, Y., \& Akinci, B. (2014). Building Information Modeling (BIM) application framework: The process of expanding from 3D to computable nD. Automation in construction, 46, 82-93.

Dong, B., Lam, K. P., Huang, Y. C., \& Dobbs, G. M. (2007). A comparative study of the IFC and gbXML informational infrastructures for data exchange in computational design support environments. In Proceedings of 10th International IBPSA Conference, Beijing, China, 1530-1537.

Duffie, A. J., \& Beckman, W. (1991). Solar Engineering of Thermal Processes, 2nd ed. John Wiley \& Sons, Inc., New York.

Eastman, C. M., Teicholz, P., Sacks, R., \& Liston, K. (2011). BIM handbook: A guide to building information modeling for owners, managers, designers, engineers and contractors. John Wiley \& Sons.

Falagas, M. E., Pitsouni, E. I., Malietzis, G. A., \& Pappas, G. (2008). Comparison of PubMed, Scopus, web of science, and Google scholar: strengths and weaknesses. The FASEB journal, 22(2), 338-342.

Fies, B. (2012). Recommendations for the integration of sustainable building assessment and benchmarking methods with BIM. eWork and eBusiness in Architecture, Engineering and Construction, Taylor \& Francis Group, London, 187-192.

Forgues, D., Iordanova, I., Valdivesio, F., \& Staub-French, S. (2012). Rethinking the cost estimating process through 5D BIM: A case study. In Proceedings of Construction Research Congress 2012, Lafayette, Indiana, United States, 778-786.

Gandhi, S., \& Jupp, J. (2014). BIM and Australian Green Star Building Certification. Computing in Civil and Building Engineering, 1, 275-282.

Gupta, A., Cemesova, A., Hopfe, C. J., Rezgui, Y., \& Sweet, T. (2014). A conceptual framework to support solar PV simulation using an open-BIM data exchange standard. Automation in Construction, 37, 166-181.

Häkkinen, T., \& Belloni, K. (2011). Barriers and drivers for sustainable building. Building Research \& Information, 39(3), 239-255.

Harding, J., Suresh, S., Renukappa, S., \& Mushatat, S. (2014). Do Building Information Modelling Applications Benefit Design Teams in Achieving BREEAM Accreditation? Journal of Construction Engineering, 2014, Article ID 390158, 1-8. 
Hwang, B. G., \& Tan, J. S. (2012). Green building project management: obstacles and solutions for sustainable development. Sustainable development, 20(5), 335-349.

Ilhan, B., \& Yaman, H. (2016). Green building assessment tool (GBAT) for integrated BIM-based design decisions. Automation in Construction, 70, 26-37.

IPCC (2011). Special Report on Renewable Energy Sources and Climate Change Mitigation, United Kingdom and New York, NY, USA, Cambridge University Press.

Jalaei, F., \& Jrade, A. (2014a). Integrating Building Information Modeling (BIM) and Energy Analysis Tools with Green Building Certification System to Conceptually Design Sustainable Buildings. ITcon, 19, 494-519.

Jalaei, F., \& Jrade, A. (2014b). Integrating BIM with Green Building Certification System, Energy Analysis and Cost Estimating Tools to Conceptually Design Sustainable Buildings. In Proceedings of Construction Research Congress 2014, Atlanta, Georgia, 140-149.

Jalaei, F., \& Jrade, A. (2015). Integrating building information modeling (BIM) and LEED system at the conceptual design stage of sustainable buildings. Sustainable Cities and Society, 18, 95-107.

Jrade, A., \& Jalaei, F. (2013). Integrating building information modelling with sustainability to design building projects at the conceptual stage. In Building simulation, 6, 4, 429-444.

Jun, H., Kim, I., Lee, Y., \& Kim, M. (2015). A Study on the BIM Application of Green Building Certification System. Journal of Asian Architecture and Building Engineering, 14(1), 9-16.

Kabassi, K., \& Cho, Y. K. (2012). BLCC Analysis derived from BIM and energy data of Zero Net Energy Test Home. In Proceedings of International Conference on Sustainable Design and Construction (ICSDC) 2010, Kansas City, Missouri, pp. 292-298.

Kim, H., \& Anderson, K. (2012). Energy modeling system using building information modeling open standards. Journal of Computing in Civil Engineering, 27(3), 203-211.

Kim, J. B., Jeong, W., Clayton, M. J., Haberl, J. S., \& Yan, W. (2015). Developing a physical BIM library for building thermal energy simulation. Automation in construction, 50, 16-28.

Kim, K., \& Yu, J. (2016a). A process to divide curved walls in IFC-BIM into segmented straight walls for building energy analysis. Journal of Civil Engineering and Management, 22(3), 333-345.

Kim, K., \& Yu, J. (2016b). BIM-based building energy load calculation system for designers. KSCE Journal of Civil Engineering, 20(2), 549-563.

Kim, S., \& Woo, J. H. (2011). Analysis of the differences in energy simulation results between building information modeling (BIM)-based simulation method and the detailed simulation method. In Proceedings of the Winter Simulation Conference 2011, Phoenix, Arizona, United States, 3550-3561.

Kofler, M. J., \& Kastner, W. (2010). A knowledge base for energy-efficient smart homes. In Proceedings of Energy Conference and Exhibition (EnergyCon), 2010, Manama, Bahrain, 85-90.

Kota, S., Haberl, J. S., Clayton, M. J., \& Yan, W. (2014). Building Information Modeling (BIM)-based daylighting simulation and analysis. Energy and Buildings, 81, 391-403.

Krygiel, E., \& Nies, B. (2008). Green BIM: successful sustainable design with building information modeling. John Wiley \& Sons.

Laine, T., Hänninen, R., \& Karola, A. (2007). Benefits of BIM in the thermal performance management. In Proceedings of the Building Simulation, Beijing, China, 1455-1461.

Lee, S., \& Song, D. (2010). Prediction and evaluation method of wind environment in the early design stage using BIM-based CFD simulation. In Proceedings of 9th World Congress on Computational Mechanics and 4th Asian Pacific Congress on Computational Mechanics, Sydney, Australia 10, 012035, 1-10.

Lee, S., Tae, S., Roh, S., \& Kim, T. (2015). Green Template for Life Cycle Assessment of Buildings Based on Building Information Modeling: Focus on Embodied Environmental Impact. Sustainability, 7(12), 16498-16512. 
Li, B., Fu, F. F., Zhong, H., \& Luo, H. B. (2012). Research on the computational model for carbon emissions in building construction stage based on BIM. Structural Survey, 30(5), 411-425.

Lin, S. H., Kensek, K., \& Haymond, L. (2010). Analytical Building Information Modeling: What is the Gap Between BIM and Energy Simulation Tools' Performance Feedback Loops? In Proceedings of Ecobuild 2010, London, United Kingdom, 1-10.

Lu, C. M., Chen, J. Y., Pan, C. A., Jeng, T. S. (2015) A BIM tool for carbon footprint assessment of building design. In Proceedings of 20th Conference on Computer-Aided Architectural Design Research in Asia. Daegu, South Korea, 447-456.

Lu, Y., Wu, Z., Chang, R., \& Li, Y. (2017). Building Information Modeling (BIM) for green buildings: A critical review and future directions. Automation in Construction, 83, 134-148.

Lu, Q., \& Lee, S. (2015). An eeBIM-Based Platform Integrating Carbon Cost Evaluation for Sustainable Building Design. In Proceedings of 2015 International Workshop on Computing in Civil Engineering, Austin, Texas, United States, 371-378.

Mah, D., Manrique, J. D., Yu, H., Al-Hussein, M., \& Nasseri, R. (2011). House construction CO2 footprint quantification: a BIM approach. Construction Innovation, 11(2), 161-178.

Marzouk, M., Hisham, M., Elsheikh M., Al-Gahtani, K. (2013). BIM for selecting environmental building materials. In Proceedings of the 7th International Structural Engineering and Construction Conference, Honolulu, Hawaii, United States, 1679-1684.

Marzouk, M., Metawie, M., Hisham, M., Al-Sulahi, I., Kamal, M., \& Al-Gahtani, K. (2014). Modeling Sustainable Building Materials in Saudi Arabia. In Proceedings of 2014 International Conference on Computing in Civil and Building Engineering, Orlando, Florida, United States, 1546-1553.

McGraw-Hill (2010). Green BIM: How building information modeling is contributing to green design and construction. Bedford, MA.

McGraw-Hill (2013). World green building trends: Business benefits driving new and retrofit market opportunities in over 60 countries. Bedford, MA.

Mousa, M., Luo, X., \& McCabe, B. (2016). Utilizing BIM and Carbon Estimating Methods for Meaningful Data Representation. Procedia Engineering, 145, 1242-1249.

National Institute of Building Sciences (NIBS) (2011). Facility Performance \& Sustainability: High Performance Building Council.

Oti, A. H., \& Tizani, W. (2015). BIM extension for the sustainability appraisal of conceptual steel design. Advanced Engineering Informatics, 29(1), 28-46.

Peng, C., \& Wu, X. (2015). Case study of carbon emissions from a building's life cycle based on BIM and Ecotect. Advances in Materials Science and Engineering, 2015, 954651, 1-15.

Raffee, S. M., Karim, M. S. A., Hassan, Z. (2016). Building sustainability assessment framework based on Building Information Modeling. ARPN Journal of Engineering and Applied Sciences, 11, 8, 5380-5384.

Reeves, T. J., Olbina, S., \& Issa, R. R. A. (2012a). Guidelines for using building information modeling (BIM) for environmental analysis of high-performance buildings. In Proceedings of 2012 International Conference on Computing in Civil Engineering, Clearwater Beach, Florida, United States, 17-20.

Reeves, T., Olbina, S., \& Issa, R. (2012b). Validation of building energy modeling tools: Ecotect ${ }^{\mathrm{TM}}$, Green Building Studio ${ }^{\mathrm{TM}}$ and IES $<$ VE $>$ TM. In Proceedings of Winter Simulation Conference 2012, Berlin, Germany, 582-593.

Reeves, T., Olbina, S., \& Issa, R. R. (2015). Guidelines for Using Building Information Modeling for Energy Analysis of Buildings. Buildings, 5(4), 1361-1388.

Robichaud, L. B., \& Anantatmula, V. S. (2010). Greening project management practices for sustainable construction. Journal of Management in Engineering, 27(1), 48-57.

Ryu, H. S. \& Park, K. S. (2016) A Study on the LEED Energy Simulation Process Using BIM. Sustainability 8, no. 2: 138 . 
Sattineni, A. (2011). Building Information Modeling: Trends in the US Construction Industry. Design Principles and Practices, 5(4), 187-200.

Schlueter, A., \& Thesseling, F. (2009). Building information model based energy/exergy performance assessment in early design stages. Automation in construction, 18(2), 153-163.

Shoubi, M. V., Bagchi, A., \& Barough, A. S. (2015). Reducing the operational energy demand in buildings using building information modeling tools and sustainability approaches. Ain Shams Engineering Journal, 6(1), 41-55.

Shrivastava, S., \& Chini, A. (2012). Using building information modeling to assess the initial embodied energy of a building. International Journal of Construction Management, 12(1), 51-63.

Solla, M., Solla, M., Ismail, L. H., \& Yunus, R. (2016). Investigation on the potential of integrating BIM into green building assessment tools. ARPN Journal of Engineering and Applied Sciences, 11, 4, 2412-2418.

Stumpf, A., Kim, H., \& Jenicek, E. (2009). Early design energy analysis using BIMs (building information models). In Proceedings of Construction Research Congress 2009, Seattle, Washington, United States, 426-436.

USGBC (2014). Introducing the new LEED Online. http://www.usgbc.org/articles/introducing-new-leed-online. Retrieved 2017-01-26.

USGBC (2017). About LEED/ Green Building Facts. www.usgbc.org. Retrieved 2017-01-26.

vom Brocke, J., Simons, A., Niehaves, B., Plattfaut, R., \& Cleven, A. (2009). Reconstructing the giant: on the importance of rigour in documenting the literature search process. In Proceedings of the 17th European Conference on Information Systems, Verona, Italy, 2-13.

Wackernagel, M., Monfreda, C., Schulz, N. B., Erb, K. H., Haberl, H., \& Krausmann, F. (2004). Calculating national and global ecological footprint time series: resolving conceptual challenges. Land use policy, 21(3), 271-278.

Wang, Y. Z., Juang, L. H., \& Liu, W. H. (2013). A New Design Concept by Using BIM for Reforming an EnergySaving Campus Building. In Applied Mechanics and Materials, 368, 1191-1195.

Webster, J. \& Watson, R.T. (2002). Analyzing the Past to Prepare for the Future: Writing a Literature Review. MIS Quarterly, 26 (2), xiii-xxiii.

Welle, B., Haymaker, J., \& Rogers, Z. (2011). ThermalOpt: A methodology for automated BIM-based multidisciplinary thermal simulation for use in optimization environments. In Building Simulation, 4, 4, 293-313.

Wiedmann, T., \& Minx, J. (2007). A definition of 'carbon footprint'. ISA Research and Consulting, Durham, United Kingdom, 1-9.

Wong, K. D., \& Fan, Q. (2013). Building information modelling (BIM) for sustainable building design. Facilities, 31(3/4), 138-157.

Wong, J. K. W., \& Kuan, K. L. (2014). Implementing 'BEAM Plus' for BIM-based sustainability analysis. Automation in Construction, 44, 163-175.

Wong, J. K. W., \& Zhou, J. (2015). Enhancing environmental sustainability over building life cycles through green BIM: A review. Automation in Construction, 57, 156-165.

Woo, J. H., Diggelman, C., \& Abushakra, B. (2011). BIM-based energy monitoring with XML parsing engine. In Proceeding of the 28th ISARC, Seoul, Korea, 544-545.

Wu, C., \& Clayton, M. (2013). BIM-based acoustic simulation Framework. In Proceeding of 30th CIB W78 International Conference, Beijing, China, 99-108.

Wu, I. C., \& Chang, S. (2013). Visual Req calculation tool for green building evaluation in Taiwan. Automation in Construction, 35, 608-617.

Wu, W., \& Issa, R. R. (2011). BIM facilitated web service for LEED automation. In Proc. 2011 ASCE International Workshop of Computing in Civil Engineering (pp. 19-22). 
Wu, W., \& Issa, R. R. (2014). BIM execution planning in green building projects: LEED as a use case. Journal of Management in Engineering, 31(1), A4014007.

Yan, W., Clayton, M., Haberl, J., Jeong, W., Kim, J.B., Kota, S., Alcocer, J.L.B. and Dixit, M., (2013). Interfacing BIM with building thermal and daylighting modeling. In Proceedings of the 13th International Conference of the International Building Performance Simulation Association, Chambery, France, 2530 .

Yoon, N., Oshitani, N. \& Ando, Y. (2014) Automated CFD simulation system with BIM for BCA Green Mark Certification. 2014 ASHRAE/IBPSA-USA Building Simulation Conference.

Yuan, Y., \& Jin, Z. (2015). Life Cycle Assessment of Building Energy in Big-Data Era: Theory and Framework. In Proceedings of 2015 International Conference on Network and Information Systems for Computers, Wuhan, China, 601-605.

Zanni, M. A., Soetanto, R., \& Ruikar, K. (2014). Defining the sustainable building design process: methods for BIM execution planning in the UK. International Journal of Energy Sector Management, 8(4), 562-587.

Zhang, C., \& Chen, J. (2015). LEED Embedded Building Information Modeling System. In Proceedings of AEI 2015, Milwaukee, Wisconsin, United States, 25-36.

Zhang, C., Chen, J., Sun, X., \& Hammad, A. (2014). Lifecycle evaluation of building sustainability using BIM and RTLS. In Proceedings of the 2014 Winter Simulation Conference, Savannah, Georgia, United States, 3236-3247.

Zuo, J., \& Zhao, Z. Y. (2014). Green building research-current status and future agenda: A review. Renewable and Sustainable Energy Reviews, 30, 271-281. 


\section{APPENDIX}

The following tables in this section show the notation of the collected literature for readers' reference.

Table A1. Publication sources of the collected green BIM papers

Journal paper (sources and number of papers)

Automation in Construction (9), Construction Innovation (2), Journal of Information Technology in Construction (2), Structural Survey (2), Journal of Engineering and Applied Science (2), Building Simulation (2), Sustainability (2), Other (21)

Conference paper (sources and number of papers)

Computer-Aided Architectural Design Research in Asia (5), Construction Research Congress (3), International Conference on Computing in Civil and Building Engineering (3), International Workshop of Computing in Civil Engineering (3), International Symposium on Automation and Robotics in Construction (2), Winter Simulation Conference (3), Building Simulation (2), International Conference on Sustainable Design, Engineering and Construction (2), Other (14)

Table A2. Citation of the collected literature and their focuses on difference BPA types

*Sequence of literature is sorted by their main focuses, publication years (chorological), and author (alphabetical).

\begin{tabular}{|c|c|c|c|c|c|c|c|c|c|c|c|c|}
\hline Main Focus & Literature citation* & T\&EA & S\&DA & W\&VA & AA & WEA & LCA & CFA & $\mathrm{CBA}$ & $\begin{array}{l}\text { GB } \\
\text { RA }\end{array}$ & $\begin{array}{l}\text { LEED } \\
\text { RA }\end{array}$ & $\begin{array}{l}\text { No. } \\
\text { types }\end{array}$ \\
\hline \multirow[t]{3}{*}{ Multiple } & Krygiel \& Nies (2008) & 1 & 1 & & & 1 & & & & & 1 & 4 \\
\hline & Azhar \& Brown (2009) & 1 & 1 & 1 & 1 & & 1 & & 1 & & 1 & 7 \\
\hline & Reeves et al. (2012a) & 1 & 1 & 1 & & 1 & 1 & 1 & 1 & & 1 & 8 \\
\hline \multirow[t]{23}{*}{ Thermal \& Energy Analysis (T\&EA) } & Laine et al. (2007) & 1 & & & & & & & & & & 1 \\
\hline & Schlueter \& Thesseling (2009) & 1 & & & & & & & & & & 1 \\
\hline & Stumpf et al. (2009) & 1 & & & & & & & & & & 1 \\
\hline & Cho et al. (2010) & 1 & & & & & & & & & & 1 \\
\hline & Kofler \& Kastner (2010) & 1 & & & & & & & & & & 1 \\
\hline & Lin et al. (2010) & 1 & & & & & & & & & & 1 \\
\hline & Kim \& Woo (2011) & 1 & & & & & & & & & & 1 \\
\hline & Welle et al. (2011) & 1 & 1 & & & & & & & & & 2 \\
\hline & Woo et al. (2011) & 1 & & & & & & & & & & 1 \\
\hline & Cho et al. (2012) & 1 & & & & & & & & & & 1 \\
\hline & Kim \& Anderson (2012) & 1 & & & & & & & & & & 1 \\
\hline & Shrivastava \& Chini (2012) & 1 & & & & & & & & & & 1 \\
\hline & Reeves et al. (2012b) & 1 & & & & & & & & & & 1 \\
\hline & Wang et al. (2013) & 1 & & & & & & & & & & 1 \\
\hline & Yan et al. (2013) & 1 & 1 & & & & & & & & & 2 \\
\hline & Alam \& Ham (2014) & 1 & & & & & & & & & & 1 \\
\hline & Chen \& Das (2014) & 1 & & & & & & & & & & 1 \\
\hline & Jalaei \& Jrade (2014a) & 1 & 1 & & & & 1 & & 1 & & 1 & 5 \\
\hline & Jalaei \& Jrade (2014b) & 1 & 1 & & & & & & 1 & & 1 & 4 \\
\hline & Cemesova et al. (2015) & 1 & & & & & & & & & & 1 \\
\hline & Kim et al. (2015) & 1 & & & & & & & & & & 1 \\
\hline & Shoubi et al. (2015) & 1 & & & & & & & & & & 1 \\
\hline & Yuan \& Jin (2015) & 1 & & & & & & & & & & 1 \\
\hline
\end{tabular}




\begin{tabular}{|c|c|c|c|c|c|c|c|c|c|c|c|c|}
\hline Main Focus & Literature citation* & T\&EA & S\&DA & W\&VA & AA & WEA & LCA & CFA & CBA & $\begin{array}{l}\text { GB } \\
\text { RA }\end{array}$ & $\begin{array}{l}\text { LEED } \\
\text { RA }\end{array}$ & $\begin{array}{l}\text { No. } \\
\text { types }\end{array}$ \\
\hline & Abanda \& Byers (2016) & 1 & & & & & & & & & & 1 \\
\hline & Choi et al. (2016) & 1 & & & & & & & & & & 1 \\
\hline & Kim \& Yu (2016a) & 1 & & & & & & & & & & 1 \\
\hline & Kim \& Yu (2016b) & 1 & & & & & & & & & & 1 \\
\hline & Ryu \& Park (2016) & 1 & & & & & & & & & 1 & 2 \\
\hline \multirow[t]{2}{*}{ Solar \& Daylighting Analysis (S\&DA) } & Gupta et al. (2014) & 1 & 1 & & & & & & & & & 2 \\
\hline & Kota et al. (2014) & & 1 & & & & & & & & & 1 \\
\hline \multirow[t]{2}{*}{ Wind \& Ventilation Analysis (W\&VA) } & Lee \& Song (2010) & & & 1 & & & & & & & & 1 \\
\hline & Yoon et al. (2014) & & & 1 & & & & & & 1 & & 2 \\
\hline Acoustic Analysis (AA) & Wu \& Clayton (2013) & & & & 1 & & & & & & & 1 \\
\hline \multirow[t]{4}{*}{ Life Cycle Analysis (LCA) } & Jrade \& Jalaei (2013) & & & & & & 1 & & 1 & & 1 & 3 \\
\hline & Díaz \& Antón (2014) & & & & & & 1 & & & & & 1 \\
\hline & Lee et al. (2015) & & & & & & 1 & & & & & 1 \\
\hline & Oti \& Tizani (2015) & & & & & & 1 & 1 & 1 & & & 3 \\
\hline \multirow[t]{10}{*}{ Carbon Footprint Analysis (CFA) } & Bank et al. (2011) & & & & & & & 1 & & & 1 & 2 \\
\hline & Mah et al. (2011) & & & & & & & 1 & & & & 1 \\
\hline & Li et al. (2012) & & & & & & & 1 & & & & 1 \\
\hline & Alwan \& Jones (2014) & & & & & & & 1 & & & & 1 \\
\hline & Chen \& Li (2014) & & & & & & & 1 & 1 & & & 2 \\
\hline & Chen \& Pan (2015) & & & & & & & 1 & & & & 1 \\
\hline & Lu \& Lee (2015) & & & & & & & 1 & 1 & & & 2 \\
\hline & Lu et al. (2015) & & & & & & & 1 & & & & 1 \\
\hline & Peng \& Wu (2015) & & & & & & & 1 & & & & 1 \\
\hline & Mousa et al. (2016) & & & & & & & 1 & & & & 1 \\
\hline \multirow[t]{7}{*}{ Cost \& Benefit Analysis (CBA) } & Kabassi \& Cho (2012) & & & & & & & & 1 & & & 1 \\
\hline & Chen et al. (2013) & & & & & & & & 1 & & & 1 \\
\hline & Cheng \& Ma (2013) & & & & & & & & 1 & & & 1 \\
\hline & Marzouk et al. (2013) & & & & & & & & 1 & & 1 & 2 \\
\hline & Akbarnezhad et al. (2014) & & & & & & & & 1 & & & 1 \\
\hline & Marzouk et al. (2014) & & & & & & & & 1 & 1 & & 2 \\
\hline & Dawood (2016) & & & & & & & & 1 & & & 1 \\
\hline \multirow{8}{*}{$\begin{array}{l}\text { Green Building Rating Analysis -other } \\
\text { than LEED } \\
\text { (GBRA) }\end{array}$} & Biswas et al. (2008) & & & & & & & & & 1 & & 1 \\
\hline & Fies (2012) & & & & & & & & & 1 & & 1 \\
\hline & Chen \& Hsieh (2013) & & & & & & & 1 & & 1 & & 2 \\
\hline & Wu \& Chang (2013) & 1 & & & & & & & & 1 & & 2 \\
\hline & Chandra \& Zhou (2014) & & & & & & & & & 1 & & 1 \\
\hline & Gandhi \& Jupp (2014) & & & & & & & & & 1 & & 1 \\
\hline & Harding et al. (2014) & & & & & & & & & 1 & & 1 \\
\hline & Wong \& Kuan (2014) & & & & & & & & & 1 & & 1 \\
\hline
\end{tabular}




\begin{tabular}{|c|c|c|c|c|c|c|c|c|c|c|c|c|}
\hline Main Focus & Literature citation* & T\&EA & S\&DA & W\&VA & AA & WEA & LCA & CFA & CBA & $\begin{array}{l}\text { GB } \\
\text { RA }\end{array}$ & $\begin{array}{l}\text { LEED } \\
\text { RA }\end{array}$ & $\begin{array}{l}\text { No. } \\
\text { types }\end{array}$ \\
\hline & Zanni et al. (2014) & & & & & & & & & 1 & & 1 \\
\hline & Jun et al. (2015) & & & & & & & & & 1 & & 1 \\
\hline & Chen \& Huang (2016) & 1 & & & & & & & & 1 & & 2 \\
\hline & Ilhan \& Yaman (2016) & & & & & & & & & 1 & & 1 \\
\hline & Raffee et al. (2016) & & & & & & & & & 1 & & 1 \\
\hline & Solla et al. (2016) & & & & & & & & & 1 & & 1 \\
\hline \multirow{9}{*}{$\begin{array}{l}\text { LEED } \\
\text { Rating Analysis } \\
\text { (LEEDRA) }\end{array}$} & Barnes \& Castro-Lacouture (2009) & & & & & & & & & & 1 & 1 \\
\hline & Azhar et al. (2011) & & & & & & & & & & 1 & 1 \\
\hline & Wu \& Issa (2011) & & & & & & & & & & 1 & 1 \\
\hline & Wu \& Issa (2014) & & & & & & & & & & 1 & 1 \\
\hline & Zhang et al. (2014) & & & & & & & & & & 1 & 1 \\
\hline & Alwan et al. (2015) & & & & & & & & & & 1 & 1 \\
\hline & Chen \& Nguyen (2015) & & & & & & & & & & 1 & 1 \\
\hline & Jalaei \& Jrade (2015) & & & & & & & & 1 & & 1 & 2 \\
\hline & Zhang \& Chen (2015) & & & & & & & & & & 1 & 1 \\
\hline & sum & 34 & 9 & 4 & 2 & 2 & 7 & 13 & 16 & 16 & 18 & \\
\hline
\end{tabular}


Table A3. Green BIM research for thermal \& energy analysis (T\&EA) - focusing on green BIM tool application

*Literature is sorted by publication years (chronological) and author (alphabetical). AP stands for analysis process.

\begin{tabular}{|c|c|c|c|c|c|c|c|}
\hline \multirow[t]{2}{*}{ Citation* } & \multicolumn{2}{|l|}{ Research goal } & \multicolumn{4}{|l|}{ Research method } & \multirow[t]{2}{*}{ Research output } \\
\hline & Detailed BPA type & Mani BIM use & Key methodology & $\begin{array}{l}\text { Case study } \\
\text { building type }\end{array}$ & $\begin{array}{l}\text { BIM authoring tool \& } \\
\text { format }\end{array}$ & $\begin{array}{l}\text { Simulation tool \& } \\
\text { analysis module }\end{array}$ & \\
\hline Laine et al. (2007) & $\begin{array}{l}\text { thermal, operational } \\
\text { energy }\end{array}$ & analysis & review & & & & framework \\
\hline Krygiel \& Nies (2008) & operational energy & analysis & case study & various & Revit & eQuest, GBS, Ecotect, IES & guideline (analysis) \\
\hline Azhar \& Brown (2009) & operational energy & analysis & interview & & & GBS, Ecotect, IES & $\begin{array}{l}\text { guideline } \\
\text { (tool selection) }\end{array}$ \\
\hline Stumpf et al. (2009) & operational energy & analysis & case study & office & Revit & GBS, eQuest & guideline (analysis) \\
\hline Cho et al. (2010) & renewable energy & analysis & case study & housing & Vico & Ecotect & guideline (analysis) \\
\hline Lin et al. (2010) & operational energy & analysis & review & & & & framework \\
\hline Kim \& Woo (2011) & operational energy & analysis & case study & office & Revit & eQuest & guideline (analysis) \\
\hline Cho et al. (2012) & operational energy & analysis & case study & & Revit/SketchUp & Energy+, IES & $\begin{array}{l}\text { guideline } \\
\text { (tool selection) }\end{array}$ \\
\hline Shrivastava \& Chini (2012) & embodied energy & analysis & case study & office & Revit & & guideline (analysis) \\
\hline Reeves et al. (2012a) & operational energy & analysis & review \& case study & school & Revit & $12 \mathrm{BEM}$ tools & $\begin{array}{l}\text { guideline } \\
\text { (tool selection) }\end{array}$ \\
\hline Reeves et al. (2012b) & operational energy & analysis & case study & & Revit & GBS, Ecotect, IES & $\begin{array}{l}\text { guideline } \\
\text { (tool selection) }\end{array}$ \\
\hline Wang et al. (2013) & operational energy & modeling & case study & school & & & guideline (modeling) \\
\hline Alam \& Ham (2014) & operational energy & analysis & case study & housing & ArchiCAD & EcoDesigner & $\begin{array}{l}\text { guideline } \\
\text { (tool selection) }\end{array}$ \\
\hline Shoubi et al. (2015) & operational energy & analysis & case study & housing & Revit & Ecotect & guideline (analysis) \\
\hline Abanda \& Byers (2016) & operational energy & analysis & case study & housing & Revit & GBS & guideline (analysis) \\
\hline Ryu \& Park (2016) & operational energy & modeling & case study & mix-use & Revit & & guideline (modeling) \\
\hline
\end{tabular}


Table A4. Green BIM research for thermal \& energy analysis (T\&EA) - focusing on green BIM tool development *Literature is sorted by publication years (chronological) and author (alphabetical).

\begin{tabular}{|c|c|c|c|c|c|c|c|c|}
\hline \multirow[t]{2}{*}{ Citation* } & \multicolumn{2}{|l|}{ Research goal } & \multicolumn{5}{|c|}{ Research method } & \multirow[t]{2}{*}{ Research output } \\
\hline & Detailed BPA type & Main BIM use & $\begin{array}{l}\text { Key } \\
\text { methodology }\end{array}$ & $\begin{array}{l}\text { Case study } \\
\text { building type }\end{array}$ & $\begin{array}{l}\text { BIM authoring } \\
\text { tool \& format }\end{array}$ & $\begin{array}{l}\text { Programing tool } \\
\& \text { language }\end{array}$ & $\begin{array}{l}\text { Simulation tool \& } \\
\text { analysis module }\end{array}$ & \\
\hline $\begin{array}{l}\text { Schlueter \& Thesseling } \\
(2009)\end{array}$ & $\begin{array}{l}\text { operational } \\
\text { energy/ exergy }\end{array}$ & visualization & case study & housing & Revit & API & EnEV & plugin (DPV) \\
\hline Kofler \& Kastner (2010) & operational energy & data integration & review & & gbXML & & OWL & $\begin{array}{l}\text { framework (gbXML \& } \\
\text { OWL) }\end{array}$ \\
\hline Welle et al. (2011) & thermal & optimization & case study & office & Digital Project & API & $\begin{array}{l}\text { Energy+, } \\
\text { ModelCenter }\end{array}$ & plugin (thermalOpt) \\
\hline Woo et al. (2011) & operational energy & data integration & case study & office & Revit & API & XML & model (B3M) \\
\hline Kim \& Anderson (2012) & operational energy & data integration & case study & office & IFC & Ruby & DOE-2 & program \\
\hline Yan et al. (2013) & thermal & data integration & case study & $\begin{array}{l}\text { BESTEST Case } \\
600\end{array}$ & Revit & API & Modelica & plugin (Revit2Modelica) \\
\hline Chen \& Das (2014) & operational energy & data integration & case study & office & gbXML & & Energy+ & web service platform \\
\hline Gupta et al. (2014) & renewable energy & data integration & case study & housing & IFC & Java & & web service platform \\
\hline Jalaei \& Jrade (2014a) & operational energy & data integration & case study & housing & Revit & API & Ecotect & plugin \\
\hline Jalaei \& Jrade (2014b) & operational energy & data integration & case study & office & Revit & API & Ecotect & plugin \\
\hline Cemesova et al. (2015) & operational energy & data integration & case study & housing & IFC & Java & PHPP & program (PassivBIM) \\
\hline Kim et al. (2015) & thermal & data integration & case study & BESTEST Case & Revit & API & Modelica & plugin (Revit2Modelica) \\
\hline Yuan \& Jin (2015) & operational energy & data integration & review & & & & & framework (Big Data) \\
\hline Choi et al. (2016) & operational energy & data integration & case study & office & IFC & & Energy+ & program \\
\hline Kim \& Yu (2016a) & operational energy & data integration & case study & $\begin{array}{l}\text { Building } \\
\text { SMART }\end{array}$ & IFC & & DOE-2 & guideline (modeling data) \\
\hline Kim \& Yu (2016b) & operational energy & data integration & case study & $\begin{array}{l}\text { Building } \\
\text { SMART }\end{array}$ & IFC & & DOE-2 & guideline (modeling data) \\
\hline
\end{tabular}


Table A5. Green BIM research for solar \& daylighting analysis ( $S \& D A)$

*Literature is sorted by publication years (chronological) and author (alphabetical).

\begin{tabular}{|c|c|c|c|c|c|c|c|c|}
\hline \multirow[t]{2}{*}{ Citation* } & \multicolumn{2}{|l|}{ Research goal } & \multicolumn{5}{|c|}{ Research method } & \multirow[t]{2}{*}{ Research output } \\
\hline & Detailed BPA type & Main BIM use & $\begin{array}{l}\text { Key } \\
\text { methodology }\end{array}$ & $\begin{array}{l}\text { Case study } \\
\text { building type }\end{array}$ & $\begin{array}{l}\text { BIM authoring } \\
\text { tool \& format }\end{array}$ & $\begin{array}{l}\text { Programing tool } \\
\& \text { language }\end{array}$ & $\begin{array}{l}\text { Simulation tool \& } \\
\text { analysis module }\end{array}$ & \\
\hline \multicolumn{9}{|c|}{ Focusing on green BIM tool application } \\
\hline Krygiel \& Nies (2008) & daylighting & analysis & case study & various & Revit & & IES, Daysim, 3ds Max & guideline (analysis) \\
\hline Azhar \& Brown (2009) & daylighting & analysis & interview & & & & GBS, Ecotect, IES & $\begin{array}{l}\text { guideline } \quad \text { (tool } \\
\text { selection) }\end{array}$ \\
\hline Reeves et al. (2012a) & daylighting & analysis & case study & school & Revit & & $12 \mathrm{BEM}$ tools & $\begin{array}{l}\text { guideline } \\
\text { selection) }\end{array}$ \\
\hline \multicolumn{9}{|c|}{ Focusing on green BIM tool development } \\
\hline Welle et al. (2011) & daylighting & optimization & case study & office & Digital Project & API & Radiance & plugin (thermalOpt) \\
\hline Yan et al. (2013) & daylighting & data integration & case study & $\begin{array}{l}\text { BESTEST Case } \\
600\end{array}$ & Revit & API & Radiance & $\begin{array}{l}\text { plugin } \\
\text { (Revit2Radiance) }\end{array}$ \\
\hline Gupta et al. (2014) & solar & data integration & case study & housing & IFC & Java & & web service platform \\
\hline Jalaei \& Jrade (2014b) & daylighting & data integration & case study & office & Revit & API & Ecotect & plugin \\
\hline Jalaei \& Jrade (2014a) & daylighting & data integration & case study & housing & Revit & API & Ecotect & plugin \\
\hline Kota et al. (2014) & daylighting & data integration & case study & housing & Revit & API & Radiance, Daysim & plugin \\
\hline
\end{tabular}


Table A6. Green BIM research for wind \& ventilation analysis (W\&VA)

*Literature is sorted by publication years (chronological) and author (alphabetical).

\begin{tabular}{|c|c|c|c|c|c|c|c|c|}
\hline \multirow[t]{2}{*}{ Citation* } & \multicolumn{2}{|l|}{ Research goal } & \multicolumn{5}{|c|}{ Research method } & \multirow[t]{2}{*}{ Research output } \\
\hline & Detailed BPA type & Main BIM use & $\begin{array}{l}\text { Key } \\
\text { methodology }\end{array}$ & $\begin{array}{l}\text { Case study } \\
\text { building type }\end{array}$ & $\begin{array}{l}\text { BIM authoring } \\
\text { tool \& format }\end{array}$ & $\begin{array}{l}\text { Programing tool } \\
\& \text { language }\end{array}$ & $\begin{array}{l}\text { Simulation tool \& } \\
\text { analysis module }\end{array}$ & \\
\hline \multicolumn{9}{|c|}{ Focusing on green BIM tool application } \\
\hline Azhar \& Brown (2009) & ventilation & analysis & interview & & & & GBS, Ecotect, IES & guideline (tool selection) \\
\hline Lee \& Song (2010) & wind & analysis & case study & tower & gbXML & & Design-Builder & guideline (analysis) \\
\hline Reeves et al. (2012a) & ventilation & analysis & case study & school & Revit & & 12 BEM tools & guideline (tool selection) \\
\hline Yoon et al. (2014) & wind \& ventilation & documentation & case study & housing & Revit & VBA & $\begin{array}{l}\text { scSTREAM, Green } \\
\text { Mark }\end{array}$ & program \\
\hline
\end{tabular}

Table A7. Green BIM research for acoustic analysis $(A A)$

*Literature is sorted by publication years (chronological) and author (alphabetical).

\begin{tabular}{|c|c|c|c|c|c|c|c|c|}
\hline \multirow[t]{2}{*}{ Citation* } & \multicolumn{2}{|l|}{ Research goal } & \multicolumn{5}{|c|}{ Research method } & \multirow[t]{2}{*}{ Research output } \\
\hline & Detailed BPA type & Main BIM use & $\begin{array}{l}\text { Key } \\
\text { methodology }\end{array}$ & $\begin{array}{l}\text { Case study } \\
\text { building type }\end{array}$ & $\begin{array}{l}\text { BIM authoring } \\
\text { tool \& format }\end{array}$ & $\begin{array}{l}\text { Programing tool } \\
\& \text { language }\end{array}$ & $\begin{array}{l}\text { Simulation tool \& } \\
\text { analysis module }\end{array}$ & \\
\hline \multicolumn{9}{|c|}{ Focusing on green BIM tool application } \\
\hline Azhar \& Brown (2009) & acoustic & analysis & interview & & & & GBS, Ecotect, IES & guideline (tool selection) \\
\hline \multicolumn{9}{|c|}{ Focusing on green BIM tool development } \\
\hline Wu \& Clayton (2013) & acoustic & visualization & case study & lecture hall & Revit & API & & plugin \\
\hline
\end{tabular}

Table A8. Green BIM research for water efficiency analysis (WEA)

*Literature is sorted by publication years (chronological) and author (alphabetical).

\begin{tabular}{|c|c|c|c|c|c|c|c|c|}
\hline \multirow[t]{2}{*}{ Citation* } & \multicolumn{2}{|l|}{ Research goal } & \multicolumn{5}{|c|}{ Research method } & \multirow[t]{2}{*}{ Research output } \\
\hline & Detailed BPA type & Main BIM use & $\begin{array}{l}\text { Key } \\
\text { methodology }\end{array}$ & $\begin{array}{l}\text { Case study } \\
\text { building type }\end{array}$ & $\begin{array}{l}\text { BIM authoring } \\
\text { tool \& format }\end{array}$ & $\begin{array}{l}\text { Programing tool } \\
\& \text { language }\end{array}$ & $\begin{array}{l}\text { Simulation tool \& } \\
\text { analysis module }\end{array}$ & \\
\hline \multicolumn{9}{|c|}{ Focusing on green BIM tool application } \\
\hline Krygiel \& Nies (2008) & water harvesting & analysis & case study & office & Revit & & & guideline (analysis) \\
\hline Reeves et al. (2012a) & water usage & analysis & case study & school & Revit & & $12 \mathrm{BEM}$ tools & guideline (tool selection) \\
\hline
\end{tabular}


Table A9. Green BIM research for lifecycle analysis (LCA)

*Literature is sorted by publication years (chronological) and author (alphabetical). EI stands for environmental impacts and EF for ecological footprint.

\begin{tabular}{|c|c|c|c|c|c|c|c|c|}
\hline \multirow[t]{2}{*}{ Citation* } & \multicolumn{2}{|l|}{ Research goal } & \multicolumn{5}{|c|}{ Research method } & \multirow[t]{2}{*}{ Research output } \\
\hline & Detailed BPA type & Main BIM use & $\begin{array}{l}\text { Key } \\
\text { methodology }\end{array}$ & $\begin{array}{l}\text { Case study } \\
\text { building type }\end{array}$ & $\begin{array}{l}\text { BIM authoring } \\
\text { tool \& format }\end{array}$ & $\begin{array}{l}\text { Programing tool } \\
\text { \& language }\end{array}$ & $\begin{array}{l}\text { Simulation tool \& } \\
\text { analysis module }\end{array}$ & \\
\hline \multicolumn{9}{|c|}{ Focusing on green BIM tool application } \\
\hline Azhar \& Brown (2009) & LCA & analysis & interview & & & & GBS, Ecotect, IES & guideline (tool selection) \\
\hline Reeves et al. (2012) & LCA & analysis & case study & school & Revit & & $12 \mathrm{BEM}$ tools & guideline (tool selection) \\
\hline Díaz \& Antón (2014) & LCA & analysis & review & & & & & framework (LCA) \\
\hline \multicolumn{9}{|c|}{ Focusing on green BIM tool development } \\
\hline Jrade \& Jalaei (2013) & EI (material) & data integration & case study & housing & Revit & API & Impact Estimator & plugin \\
\hline Jalaei \& Jrade (2014a) & EI (material) & data integration & case study & housing & Revit & API & Impact Estimator & plugin \\
\hline Lee et al. (2015) & EI (material) & analysis & case study & housing & Revit & API & Korea LCI & plugin \\
\hline Oti \& Tizani (2015) & EF (structural) & optimization & case study & office & Revit & API & $\begin{array}{l}\text { Wackernagel et al. } \\
(2004)\end{array}$ & plugin \\
\hline
\end{tabular}


Table A10. Green BIM research for carbon footprint analysis (CFA)

*Literature is sorted by publication years (chronological) and author (alphabetical).

\begin{tabular}{|c|c|c|c|c|c|c|c|c|}
\hline \multirow[t]{2}{*}{ Citation* } & \multicolumn{2}{|l|}{ Research goal } & \multicolumn{5}{|c|}{ Research method } & \multirow[t]{2}{*}{ Research output } \\
\hline & Detailed BPA type & BIM use & $\begin{array}{l}\text { Key } \\
\text { methodology }\end{array}$ & $\begin{array}{l}\text { Case study } \\
\text { building type }\end{array}$ & $\begin{array}{l}\text { BIM authoring } \\
\text { tool \& format }\end{array}$ & $\begin{array}{l}\text { Programing tool } \\
\& \text { language }\end{array}$ & $\begin{array}{l}\text { Simulation tool \& } \\
\text { analysis module }\end{array}$ & \\
\hline \multicolumn{9}{|c|}{ Focusing on green BIM tool application } \\
\hline Mah et al. (2011) & CFA (construction) & analysis & case study & housing & $\begin{array}{l}\text { Virtual } \\
\text { Construction }\end{array}$ & & Landmark Group & guideline (analysis) \\
\hline Reeves et al. (2012) & CFA (LCA) & analysis & case study & school & Revit & & $12 \mathrm{BEM}$ tools & guideline (tool selection) \\
\hline Alwan \& Jones (2014) & CFA (material) & analysis & case study & visitor center & & & ICE & guideline (analysis) \\
\hline Chen \& Li (2014) & CFA (LCA) & analysis & case study & school & Revit & & eQuest, CDM & guideline (analysis) \\
\hline Peng \& Wu (2015) & CFA (LCA) & analysis & case study & office & Revit & & Ecotect, IPCC & guideline (analysis) \\
\hline \multicolumn{9}{|c|}{ Focusing on green BIM tool development } \\
\hline Bank et al. (2011) & CFA (material) & optimization & case study & envelope & Revit & API, Java & $\begin{array}{l}\text { AnyLogicTM, } \\
\text { LEED }\end{array}$ & plugin \\
\hline Li et al. (2012) & CFA (material) & data integration & case study & $\begin{array}{l}\text { exhibition } \\
\text { hall }\end{array}$ & Revit & & BEES & plugin \\
\hline Chen \& Hsieh (2013) & CFA (greening) & optimization & case study & landscape & Revit & API & & plugin \\
\hline Chen \& Pan (2015) & CFA (energy) & optimization & case study & housing & Revit & API & Lin et al. (2014) & plugin \\
\hline Lu \& Lee (2015) & CFA (LCA) & data integration & review & & & & & framework (integration) \\
\hline Lu et al. (2015) & CFA (energy) & optimization & case study & office & Revit & $\mathrm{C}++$ & $\begin{array}{l}\text { eQuest, LIDX, } \\
\text { Fuzzy } \\
\text { PROMETHEE }\end{array}$ & program \\
\hline Oti \& Tizani (2015) & CFA (material) & analysis & case study & office & Revit & API & $\begin{array}{l}\text { Wiedmann } \quad \& \\
\text { Minx (2007) }\end{array}$ & plugin \\
\hline Mousa et al. (2016) & CFA (energy) & optimization & review & housing & Revit & & & framework \\
\hline
\end{tabular}


Table A11. Green BIM research for cost and benefit analysis (CBA)

*Literature is sorted by publication years (chronological) and author (alphabetical). BLCC stands for building life cycle cost, while BELCC stands for building energy life cycle cost.

\begin{tabular}{|c|c|c|c|c|c|c|c|c|}
\hline \multirow[t]{2}{*}{ Citation* } & \multicolumn{2}{|l|}{ Research goal } & \multicolumn{5}{|c|}{ Research method } & \multirow[t]{2}{*}{ Research output } \\
\hline & Detailed BPA type & Main BIM use & $\begin{array}{l}\text { Key } \\
\text { methodology }\end{array}$ & $\begin{array}{l}\text { Case study } \\
\text { building type }\end{array}$ & $\begin{array}{l}\text { BIM authoring } \\
\text { tool \& format }\end{array}$ & $\begin{array}{l}\text { Programing tool } \\
\text { \& language }\end{array}$ & $\begin{array}{l}\text { Simulation tool \& } \\
\text { analysis module }\end{array}$ & \\
\hline \multicolumn{9}{|c|}{ Focusing on green BIM tool application } \\
\hline Azhar \& Brown (2009) & BELCC & analysis & interview & & & & GBS, Ecotect, IES & guideline (tool selection) \\
\hline Kabassi \& Cho (2012) & BLCC & analysis & case study & housing & & & & guideline (analysis) \\
\hline Reeves et al. (2012) & BELCC & analysis & case study & school & Revit & & $12 \mathrm{BEM}$ tools & guideline (tool selection) \\
\hline Chen \& Li (2014) & BLCC & analysis & case study & school & Revit & & eQuest & guideline (analysis) \\
\hline \multicolumn{9}{|c|}{ Focusing on green BIM tool development } \\
\hline Chen et al. (2013) & BLCC & analysis & review & & & & & framework (analysis) \\
\hline Cheng \& Ma (2013) & demolition & analysis & case study & housing & Revit & API & & plugin \\
\hline Jrade \& Jalaei (2013) & hard cost & analysis & case study & housing & Revit & API & & plugin \\
\hline Marzouk et al. (2013) & BLCC & analysis & case study & housing & Telka & API & & plugin \\
\hline Akbarnezhad et al. (2014) & demolition & analysis & case study & housing & Telka, IFC & VBA & & program \\
\hline Jalaei \& Jrade (2014 a) & hard cost & analysis & case study & housing & Revit & API & & plugin \\
\hline Jalaei \& Jrade (2014 b) & hard cost & analysis & case study & office & Revit & API & & plugin \\
\hline Marzouk et al. (2014) & BLCC & analysis & case study & housing & Telka & API & & plugin \\
\hline Jalaei \& Jrade (2015) & soft cost & analysis & case study & housing & Revit & API & & plugin \\
\hline Lu \& Lee (2015) & carbon & data integration & review & & & & & framework (integration) \\
\hline Oti \& Tizani (2015) & BLCC & analysis & case study & office & Revit & API & & plugin \\
\hline Dawood (2016) & BLCC & optimization & review & & Revit & Dynamo & GBS & framework \\
\hline
\end{tabular}


Table A12. Green BIM research for green building rating analysis (GBRA)

*Literature is sorted by publication years (chronological) and author (alphabetical).

\begin{tabular}{|c|c|c|c|c|c|c|c|c|}
\hline \multirow[t]{2}{*}{ Citation* } & \multicolumn{2}{|l|}{ Research goal } & \multicolumn{5}{|l|}{ Research method } & \multirow[t]{2}{*}{ Research output } \\
\hline & Detailed BPA type & Main BIM use & $\begin{array}{l}\text { Key } \\
\text { methodology }\end{array}$ & $\begin{array}{l}\text { Case study } \\
\text { building type }\end{array}$ & $\begin{array}{l}\text { BIM authoring } \\
\text { tool \& format }\end{array}$ & $\begin{array}{l}\text { Programing tool } \\
\& \text { language }\end{array}$ & $\begin{array}{l}\text { Simulation tool \& } \\
\text { analysis module }\end{array}$ & \\
\hline \multicolumn{9}{|c|}{ Focusing on green BIM tool application } \\
\hline Biswas et al. (2008) & 4 GBRS & analysis & review & & & & & review \\
\hline Harding et al. (2014) & BREEAM, UK & analysis & review & & & & & suggestion (research) \\
\hline Gandhi \& Jupp (2014) & $\begin{array}{l}\text { Green } \\
\text { Australia }\end{array}$ & analysis & $\begin{array}{l}\text { interview } \quad \& \\
\text { case study }\end{array}$ & office & & & & framework (integration) \\
\hline Wong \& Kuan (2014) & BEAM, HK & analysis & $\begin{array}{l}\text { interview } \\
\text { case study }\end{array}$ & housing & Revit & & & framework (integration) \\
\hline Zanni et al. (2014) & BREEAM, UK & analysis & $\begin{array}{l}\text { interview \& } \\
\text { modelling }\end{array}$ & & & & & $\begin{array}{l}\text { framework } \\
\text { (BIM process) }\end{array}$ \\
\hline Solla et al. (2016) & $\begin{array}{l}\text { LEED, } \\
\text { Green Star }\end{array}$ & analysis & review & & & & & $\begin{array}{l}\text { comparison } \\
\text { (BIM potential) }\end{array}$ \\
\hline \multicolumn{9}{|c|}{ Focusing on green BIM tool development } \\
\hline Fies (2012) & Super Building, EU & data integration & review & & & & & framework (integration) \\
\hline Chen \& Hsieh (2013) & EEWH, Taiwan & analysis & case study & landscape & Revit & API & & plugin \\
\hline Wu \& Chang (2013) & EEWH, Taiwan & analysis & case study & housing & Bentley & VBA & Req & program \\
\hline Chandra \& Zhou (2014) & $\begin{array}{ll}\text { Green } & \text { Mark, } \\
\text { Singapore } & \end{array}$ & analysis & case study & building & Revit & API & CUI & plugin \\
\hline Yoon et al. (2014) & $\begin{array}{l}\text { Green } \\
\text { Singapore }\end{array}$ & documentation & case study & housing & Revit & VBA & scSTREAM & plugin \\
\hline Marzouk et al. (2014) & $\begin{array}{l}\text { SAGRS, } \quad \text { Saudi } \\
\text { Arabia }\end{array}$ & optimization & case study & housing & Telka & API & & plugin \\
\hline Jun et al. (2015) & $\begin{array}{l}\text { G-SEED, South } \\
\text { Korea }\end{array}$ & data integration & case study & housing & Revit, gbXML & & & framework (analysis) \\
\hline Chen \& Huang (2016) & EEWH, UK & optimization & case study & envelop & Revit & Dynamo & & plugin \\
\hline Ilhan \& Yaman (2016) & BREEAM, UK & analysis & case study & retail & ArchiCAD, IFC & $\mathrm{C} \#$ & & program \\
\hline Raffee et al. (2016) & GBI, Malaysia & data integration & review & & IFC & VBA & & framework (analysis) \\
\hline
\end{tabular}


Table A13. Green BIM research for LEED rating analysis (LEEDRA)

*Literature is sorted by publication years (chronological) and author (alphabetical).

\begin{tabular}{|c|c|c|c|c|c|c|c|c|}
\hline \multirow[t]{2}{*}{ Citation* } & \multicolumn{2}{|l|}{ Research goal } & \multicolumn{5}{|l|}{ Research method } & \multirow[t]{2}{*}{ Research output } \\
\hline & Detailed BPA type & Main BIM use & $\begin{array}{l}\text { Key } \\
\text { methodology }\end{array}$ & $\begin{array}{l}\text { Case study } \\
\text { building type }\end{array}$ & $\begin{array}{l}\text { BIM authoring } \\
\text { tool \& format }\end{array}$ & $\begin{array}{l}\text { Programing tool } \\
\& \text { language }\end{array}$ & $\begin{array}{l}\text { Simulation tool \& } \\
\text { analysis module }\end{array}$ & \\
\hline \multicolumn{9}{|c|}{ Focusing on green BIM tool application } \\
\hline Biswas et al. (2008) & general & analysis & review & & & & & framework (integration) \\
\hline Krygiel \& Nies (2008) & WE, EA, IEQ & analysis & case study & various & Revit & & $\begin{array}{l}\text { eQuest, } \quad \text { GBS, } \\
\text { Ecotect, IES }\end{array}$ & guideline (analysis) \\
\hline Azhar \& Brown (2009) & general & analysis & interview & & & & GBS, Ecotect, IES & guideline (tool selection) \\
\hline $\begin{array}{l}\text { Barnes \& Castro-Lacouture } \\
(2009)\end{array}$ & SS, MR & analysis & case study & school & Revit & & & guideline (analysis) \\
\hline Azhar et al. (2011) & WE, EA & analysis & $\begin{array}{l}\text { interview \& } \\
\text { mapping }\end{array}$ & school & Revit & & IES & framework (BIM process) \\
\hline Reeves et al. (2012a) & general & analysis & case study & school & Revit & & $12 \mathrm{BEM}$ tools & guideline (tool selection) \\
\hline Wu \& Issa (2014) & general & analysis & review & & & & & framework (integration) \\
\hline Alwan et al. (2015) & EA & analysis & case study & museum & Revit & & IES & guideline (analysis) \\
\hline Ryu \& Park (2016) & EA & analysis & case study & mix-use & Revit & & DOE-2 & guideline (modeling) \\
\hline Solla et al. (2016) & general & analysis & review & & & & & $\begin{array}{l}\text { comparison } \\
\text { potential) }\end{array}$ \\
\hline \multicolumn{9}{|c|}{ Focusing on green BIM tool development } \\
\hline Bank et al. (2011) & MR & optimization & case study & envelope & Revit & API & AnyLogicTM & plugin \\
\hline Wu \& Issa (2011) & general & documentation & review & & & & & framework (integration) \\
\hline Jrade \& Jalaei (2013) & MR & analysis & case study & housing & Revit & API & & plugin \\
\hline Marzouk et al. (2013) & MR & optimization & case study & housing & Telka & API & & plugin \\
\hline Jalaei \& Jrade (2014a) & EA, MR & analysis & case study & housing & Revit & API & Ecotect & plugin \\
\hline Jalaei \& Jrade (2014b) & EA, MR & analysis & case study & office & Revit & API & Ecotect & plugin \\
\hline Zhang et al. (2014) & MR & data integration & review & & & & & framework (integration) \\
\hline Chen \& Nguyen (2015) & SS & analysis & case study & office & Revit & API & & plugin \\
\hline Jalaei \& Jrade (2015) & general & analysis & case study & housing & Revit & API & & plugin \\
\hline Zhang \& Chen (2015) & MR & data integration & review & & & & & framework (integration) \\
\hline
\end{tabular}

